\title{
NON-GENETIC FACTORS AFFECTING SOMATIC CELL COUNT, MILK UREA CONTENT, TEST-DAY MILK YIELD AND MILK PROTEIN PERCENT IN DAIRY CATTLE OF THE CZECH REPUBLIC USING INDIVIDUAL TEST-DAY RECORDS \\ Oudah, E. Z. M. \\ Department of Animal Production, Faculty of Agriculture, Mansoura University, PC: 35516, Mansoura, Egypt, E-mail: eoudah@uoguelph.ca
}

\begin{abstract}
This study had two aims. Firstly, to determine the associations of month of recording (MOR) and days in milk (DIM) with somatic cell count (SCC), milk urea concentration (MU) and milk production traits (i.e. test-day milk yield, TDM; milk protein percentage, PP and milk protein yield, PY). Secondly, to evaluate the associations among SCC, MU and milk production traits by analyzing individual monthly test-day records for dairy cows raised in the Czech part of the Czech Republic. A total number of 33,881 individual test-day milk records involving 15,565 dairy cows for a 12-month period between January and December 2001 enrolled in Database Computer Center belonging to Czech Moravian Breeders' Corporation, Inc., Hiradistko, The Czech Republic were used. Data were analyzed using General Linear Model procedure (GLM) using Statistical Analysis System (SAS, 2004). The MOR and DIM had highly significant $(P<0.001)$ effects on the studied traits. The SCC reached the maximum level in September $(504,000)$ associated to the lowest TDM $(19.9 \mathrm{~kg})$ and the lowest SCC in December $(320,000)$ and February $(335,000 \mathrm{cell} / \mathrm{ml})$. Least squares means of TDM, categorized by $30-d$ increments of DIM, paralleled reversible changes in PP and followed a curvilinear shape. SCC reached to the peak in the $2^{\text {nd }}$ and $3^{\text {rd }}$ months of lactation then decreased gradually to the end of lactation. MU was lower $(30.5 \mathrm{mg} / \mathrm{dl})$ during the first 30 DIM compared with all other DIM categories. The statistical analysis of TDM, PY and SCC by MU showed that as MU increased, TDM, PY increased and SCC decreased. MU, SCC, PP and PY were significantly different among TDM categorized. Each of PP and SCC measures inversely associated with TDM, meanwhile MU paralleled change with TDM. Somatic cell count measures showed a paralleled change with PP. The effects of environmental variables and associations among traits must be taken into consideration when cows are evaluated.
\end{abstract}

Keywords: dairy cattle, days in milk, environmental effects, milk urea nitrogen

\section{INTRODUCTION}

Changing genetic evaluation methods from a 305-day lactation model to a test-day model has many ramifications that need to be considered (Schaeffer et al., 2000). Somatic cell count and MU make provision for the determination of important aids for nutrition and health management in the herd. The SCC can serve as an indicator of possible udder problems specially mastitis while the MU can be an indicator of the nutritional status of the herd. The interpretation of these traits and parameters assists the breeders in effectively selecting cows and in making important management decisions with regard to the health status and nutrition of their herds. 
Oudah, E. Z. M.

Somatic cell count in milk is a long-established parameter of milk quality (Coffey et al., 1986 and Weller et al., 1992). The SCC is important to dairy producers both because counts that are too high can lead to poor quality or even unsaleable milk and SCC can be used to monitor mastitis incidence in the herd (Haile-Mariam et al., 2001 and Mostert et al., 2004). In addition, SCC is frequently used to determine quality payments to dairy producers (Wattiaux et al., 2005). Another reason to reduce the SCC is to decrease the bulk milk SCC, which above a certain value results in a discount in milk price for the farmer (Calus et al., 2006). Somatic cells are always present in milk and they increase due to mammary gland infections (Atakan, 2008). Management and breeding decisions aim to reduce the SCC as a way to decrease the incidence of mastitis (Emanuelson et al., 1988; Weller et al., 1992 and Philipsson et al., 1995).

The cost of mastitis to the dairy industry is associated with lost yield, discarded milk, cost of veterinarian and treatment, herdsman's time, extended calving intervals and extra services per conception and culling (Wicks and Leaver 2006). In Canada, Dürr et al. (2008) working on Ayrshire and Holstein cows concluded that sub-clinical mastitis assessed by SCC definitely jeopardizes daily milk yield in dairy cows. They concluded also that daily milk losses caused by changes in LnSCC depend on breed, parity and stage of lactation, and ignoring these factors leads to significant errors in estimating losses associated to subclinical mastitis. Moreover, lower SCC levels have been shown to be related to higher milk yield and better dairy product quality and therefore have important economic value (Kiiman and Kaart 2004).

The European Union requires that milk used for dairy products sold in its territory have SCC levels below $400,000 \mathrm{cells} / \mathrm{ml}$ and New Zealand and Australia require similar levels. Canada requires milk to have below 500,000 cells/ml (Sargeant et al., 1998 and Norman et al., 2000). In the United States, the current national penalty level is $750,000 \mathrm{cells} / \mathrm{ml}$ and over. Many US (organic) dairy cooperatives also require SCC to be less than 400,000 cells/ml (Van Schaik et al., 2002). De Haas et al. (2008) obtained a wide range of genetic correlations between udder health traits and several SCC traits. Rekik et al. (2008) reported that DIM, calving age, and calving to conception interval were all together important sources of variation for SCC mainly in the first and second parities.

Additionally, MU is a relatively new test developed to assess dietary needs of lactating dairy cows (Spicer et al., 2000). In USA, Jonker et al. (2002) noticed that $40 \%$ of the dairy farmers in Maryland and Virginia States did not know what milk urea nitrogen (MUN) was, and $89.5 \%$ did not routinely run the MUN test. In Canada, $73 \%$ of Ontario farmers use Ontario Dairy Herd Improvement services and only $18 \%$ of these farmers test for MUN (Calberry, 2003). Concentrations of MUN in milk are variable from herd-toherd and between cows in the same herd (Arunvipas et al., 2003). High values of MUN indicate an imbalance of protein and energy (Wood et al., 2003). The concentration of urea is known to vary with the amount of protein in the diet, amount of urine excreted, water intake, dry matter intake, sampling methods, breed, season, herd management, energy intake and 
parity (Godden et al., 2001b and Ferguson 2002). Godden et al. (2001b) mentioned that information has been lacking for interpreting MU data, given the various sampling, cow (breed, parity, DIM), seasonal, herd management, and nutritional management factors that can all influence MU. The benefits of using $\mathrm{MU}$ as a monitoring tool to help optimize the efficiency of dietary protein utilization include improved efficiency and reduced cost of production, reduced nitrogen excretion into the environment and improved fertility (Baker et al., 1995; Kohn et al., 2005; Stoop et al., 2007). MUN concentrations can be used as a practical tool to monitor dietary crude protein and energy intake relative to requirements. This type of monitoring can play an important role in dairy herd management, because 1 ) excess protein $(N)$ intake may impair reproductive performance; 2) consumption of excess CP increases energy requirements; 3) protein supplements are costly feed ingredients; and 4) excess $\mathrm{N}$ excretion has a negative environmental impact (Broderick and Clayton, 1997).

Besides the variation in MUN related to the protein to energy ratio of the diet consumed (Oltner and Wiktorsson 1983; Oltner et al., 1985; Broderick and Clayton 1997; Garcia et al., 1997 and Wood et al., 2003), there are managerial and productive factors associated with MU like milk yield and fat and protein contents (Carlsson et al., 1995; Godden et al., 2001; RajalaSchultz and Saville 2003 and Hojman et al., 2004), SCC (Hojman et al., 2004), parity (Butler et al., 1995; Carlsson et al., 1995 and Broderick and Clayton 1997), DIM (Carlsson et al., 1995 and Hojman et al., 2004), month of the year (Hojman et al., 2004), breed (Johnson and Young 2003) and live body weight (Kohn et al., 2002 and Hojman et al., 2005). Milk urea nitrogen might be used as a selection tool, and therefore, information on factors affecting it is needed (Stoop et al., 2007).

On the other side, protein content of milk also has received much attention from producers of milk and processors of dairy products. Increased recognition of the value of protein in milk has led processors to pay a premium for milk exceeding minimum protein percentages. To take advantage of such pricing schemes, producers have considered protein performance for culling decisions and breeding plans (Wiggans 1986). In most countries, protein yield takes an important place in the national selection index (Miglior et al., 2006) and has been associated with an increase in MUN. Field studies have been lacking that investigate the relationship between MU and efficiency of milk production.

The objectives of the present study were: 1) To investigate the effect of month of recording (MOR) and days in milk (DIM) on somatic cell count (SCC), milk urea concentration (MU), and milk production traits (i.e. test-day milk yield, milk protein percentage and milk protein yield) and 2) to evaluate the associations among MU, SCC and milk production traits by analyzing individual monthly cow test-day records for dairy cattle raised in the Czech part of the Czech Republic. 
Oudah, E. Z. M.

\section{MATERIALS AND METHODS}

Data

A total of 33,881 individual monthly cow test-day records involving 15,565 dairy cows including cow' number, date of test, calving date, test-day milk yield (TDM, kg), somatic cell count (SCC, 1000 cells $/ \mathrm{ml}$ ), milk urea concentration (MU, mg/dl) and percentage of milk protein (PP, \%) from January to December 2001 was used in the statistical analyses. The days in milk (DIM) was defined as the interval between date of calving and milk test date. The data were enrolled in Database Computer Center belonging to Czech Moravian Breeders' Corporation, Inc., (Czech Member of International Committee for Animal Recording, ICAR), Hiradistko, Czech Republic. Apparently, the majority of the cows belong to either Holstein or Czech Spotted breed and very small number of cows was Jersey. The cows were in different parities, but no distinction was made for breed or parity in the data set used in the study. Methods used for milk recording were A4 and AT (ICAR norms). From 3788 herds, 98.2 and $1.8 \%$ herds were recorded using A4 and AT methods, respectively. Generally, the total mixed ration feeding was the most common management practices on the farms located at the Czech part of $\mathrm{CZ}$. The managerial and nutritional practices were nearly similar across farms. To convert MU (milk urea content) to MUN (Milk urea nitrogen), the following conversion formula can be used (after Kureoja and Kaart 2004): Milk urea content $(\mathrm{MU}, \mathrm{mg} / \mathrm{dl}) \times 0.467=$ Milk urea nitrogen (MUN, mg/dl) or the formula (after Godden et al., 2001b): Milk urea content $(\mathrm{MU}, \mathrm{mmol} / \mathrm{L}) \times 2.8=$ Milk urea nitrogen $(\mathrm{MUN}, \mathrm{mg} / \mathrm{dl})$.

\section{Laboratory procedures}

Individual test-day milk samples were analyzed in the Milk Testing Laboratory of Buštehrad. Somatic cell count was estimated using Bentley Instruments (Somacount 3000, the instrument utilize a laser based flow cytometry). Protein percentage was estimated also using Bentley Instruments (Bentley 2000, infrared transmission photometer). The direct specific enzymatic method UREAKVANT (made by Agrosluzby Morava a Slezko) was used for the routine determination of the MU

Independent variables (fixed effects)

Categories and computing limitations: To study the effect of fixed effects on dependent variables, the independent variables were classified into categories. Categories were selected so that the middle category encompassed the observed mean of the trait, so the upper- and lower most categories contained enough observations to be statistically and biologically meaningful. The preliminary statistical analyses showed that inclusion of calendar month in the statistical models yielded a better fit than did season of the year. Therefore, MORs were classified into 12 classes according to calendar month from January to December. Days in milk (stage of lactation) were grouped into eleven 30-day classes with those greater than $300 \mathrm{~d}$ grouped into one category (category 11). Because SCC is frequently elevated shortly after calving, use of SCC during this period is often not recommended (Dohoo 1993). In addition, Ruegg et al. (2008) pointed out that the evaluation of SCC in fresh cows should not be performed until at least 5 
days post-calving, so that DIM less than five days and more than 400 days were excluded. Milk urea content was grouped by increments of $10 \mathrm{mg} / \mathrm{dl}$ with those less than $15 \mathrm{mg} / \mathrm{dl}$ grouped into one category and greater than 55 $\mathrm{mg} / \mathrm{dl}$ as other category. Milk urea content less than 10 and more than 60 $\mathrm{mg} / \mathrm{dl}$ was excluded. Test-day milk yield was grouped by increments of $5 \mathrm{~kg}$ with those less than or equal $15 \mathrm{~kg}$ grouped into one category, and greater than $30 \mathrm{~kg}$ as other category. Test-day milk yields less than 3 and more than $60 \mathrm{~kg}$ was excluded. Milk protein percentage was categorized into increments of $0.2 \%$ beginning with less than $3 \%$ and ending with more than $3.8 \%$. Milk protein percentage less than 2 and more than $5 \%$ was excluded. The summation of all previously mentioned limitations for original test-day records caused the elimination of approximately one third of the records (from 31,881 to 22,153 test-day records).

Shook (1982) proposed expressing SCC on a log (base 2) scale (somatic cell score, SCS), which would result in a more normalized distribution. A further advantage of expressing SCC as SCS is that regression of milk yield on SCS is essentially linear in contrast to the relationship of yield with SCC. Since healthy cows do maintain low SCC in milk (Capuco and Akers, 1999), so that cows with a SCS of $0-3$ are generally considered uninfected while cows with a SCS of 7-9 are considered clinically infected with mastitis. The breeder should strive to maximize the percentage of cows in the 0-3 category and minimize the percentage in the 7-9 category. For this purpose, SCS levels ( $0-9$ classes) were categorized into five categories as follows: $0-3,4,5,6$ and 7-9 for categories $1,2,3,4$ and 5, respectively.

\section{Dependent variables (studied traits)}

Dependent variables were TDM, PP, PY, MU and SCC. Moreover, to evaluate SCC, two methods of evaluating were used: the first was the actual somatic cell count (SCC, $1000 \mathrm{cell} / \mathrm{ml})$. Somatic cell count less than 1000 and more than 7,000,000 cell/ml milk was excluded. The second method was linear somatic cell count score (SCS) defined by Raubertas and Shook (1982). To approximate the normal distribution, a natural logarithmic transformation of the SCC was used. A score of 0 to 9 was assigned to each sample day according to SCC level. Each integer increase (or decrease) in linear score is associated with a doubling (or halving) of the actual SCC as shown in Table 1.

Table 1: Relationship between SCC scores (SCS) and somatic cell count (Raubertas and Shook 1982)

\begin{tabular}{ccccc}
\hline SCS & $\begin{array}{c}\text { SCC range } \\
(\mathbf{x 1 0 0 0})\end{array}$ & $\begin{array}{c}\text { Mid-point SCC } \\
(\mathbf{x ~ 1 0 0 0 )}\end{array}$ & \begin{tabular}{c} 
Milk Production Loss (lbs/305-day) \\
\cline { 3 - 5 }
\end{tabular} & $\begin{array}{c}\text { Lactation 1 } \\
\text { Lactation 2 }\end{array}$ \\
\hline 0 & $0-18$ & 12,5 & --- & -- \\
1 & $19-35$ & 25 & --- & -- \\
2 & $36-71$ & 50 & --- & -- \\
3 & $72-141$ & 100 & -204 & -808 \\
4 & $142-283$ & 200 & -408 & -1224 \\
5 & $284-565$ & 400 & -612 & -1632 \\
6 & $566-1130$ & 800 & -816 & -2040 \\
7 & $1131-2262$ & 1600 & -1020 & -2448 \\
8 & $2263-4523$ & 3200 & -1224 & -2864 \\
9 & $4524-9999$ & 6400 & -1432 & \\
\hline
\end{tabular}


Oudah, E. Z. M.

The scores have a number of advantages over SCC (Raubertas and Shook 1982) as mentioned above.

\section{Statistical analyses}

Information on cow's number, cow's TDM (kg), PP (\%), SCC (1000 cell $/ \mathrm{ml})$, DIM (day), MU (mg/dl) on each test day record were available. Missing values in any record caused a record to be excluded if the analysis included that variable. Data were analyzed using General Linear Model procedure (GLM). Data analysis was performed using the Statistical Analysis System (SAS/STAT 9.1 User's Guide, 2004). To control the repeated measures on different test-day record at the same cow level, repeated measures statements were used in the statistical analyses. In order to allow the inclusion of repeated measures statements in the statistical model, a minimum of two dependent variables per statistical model was imposed for the statistical analysis by SAS (2004) as shown in Table 2.

Table 2: A list of dependent variables (traits) and independent variables (fixed effects) and their definitions used in the statistical model for bivariate analysis of variance ${ }^{*}$

\begin{tabular}{lcccccc}
\hline \multirow{2}{*}{$\begin{array}{l}\text { Dependent variable } \\
\text { (trait) }\end{array}$} & \multicolumn{6}{c}{ Independent variable (Fixed effect) } \\
\cline { 2 - 7 } & MOR & DIM & SSC & MUC & MYC & PPC \\
\hline SCC and SCS & $X$ & $X$ & & $X$ & $X$ & $X$ \\
MU and PY & $X$ & $X$ & $X$ & & $X$ & $X$ \\
TDM and PY & $X$ & $X$ & $X$ & $X$ & & $X$ \\
PP and PY & $X$ & $X$ & $X$ & $X$ & $X$ & \\
\hline
\end{tabular}

${ }^{*}$ MOR=month of recording, DIM=days in milk (day), MUC=milk urea content categories $(\mathrm{mg} / \mathrm{dl}), \mathrm{PPC}=$ protein percentage categories $(\%), \mathrm{MYC}=$ test-day milk yield categories $(\mathrm{kg})$, SSC=somatic cell score categories, SCC = Somatic cell count $(\times 1000)$, SCS= Somatic cell score, TDM= Test-day milk yield $(\mathrm{kg}), \mathrm{MU}=$ Milk urea content $(\mathrm{mg} / \mathrm{dl})$, $\mathrm{PP}=$ Protein percentage $(\%), \mathrm{PY}=$ Protein yield $(\mathbf{k g})$

Protein yield trait was added to each of MU, TDM and PP statistical model to overcome the repeated measure statement that needs to multivariate- not univariate analysis to enable an analysis of MU, TDM, and PP for different levels of each variable. Because of these computational limitations, only two traits were analyzed simultaneously using the same statistical model and therefore, the traits were grouped in four statistical models as follows: 1) SCC and SCS, 2) MU and PY, 3) TDM and PY and 4) PP and PY. Whereas there are three models for PY, the last one (PP and PY) was used in the present results (Table 2).

An F-test was conducted to obtain an indication about the importance (level of significance, $p$ ) of the fixed effects. Multiple comparisons were made with $P$-values adjusted using Tukey's procedure. Test of significance between LSM of the levels in each fixed effect was made using the option: PDIFF adjust=Tukey in the LSMEAN statement (Tukey-Kramer test, SAS, 2004).

A general linear model (Proc GLM, SAS, Version 9.1) was used to analyze records of TDM, PP, PY, SCC, SCS and MU and included the fixed effects of month of recording and DIM for all variables as well as the other categories according to the variable. The dependent and independent 
variables used in the statistical model for each two traits (bivariate analysis) are given in Table 2 .

The following general linear fixed model was used to study the factors affecting the total variation in somatic cell count measures (SCC and SCS):

$$
\mathrm{Y}_{i j k l m n}=\mu+\mathrm{MOR}_{i}+\mathrm{DIM}_{j}+\mathrm{MUC}_{k}+\mathrm{MYC}_{l}+\mathrm{PPC}_{m}+\mathrm{e}_{i j k l m n}
$$
where:

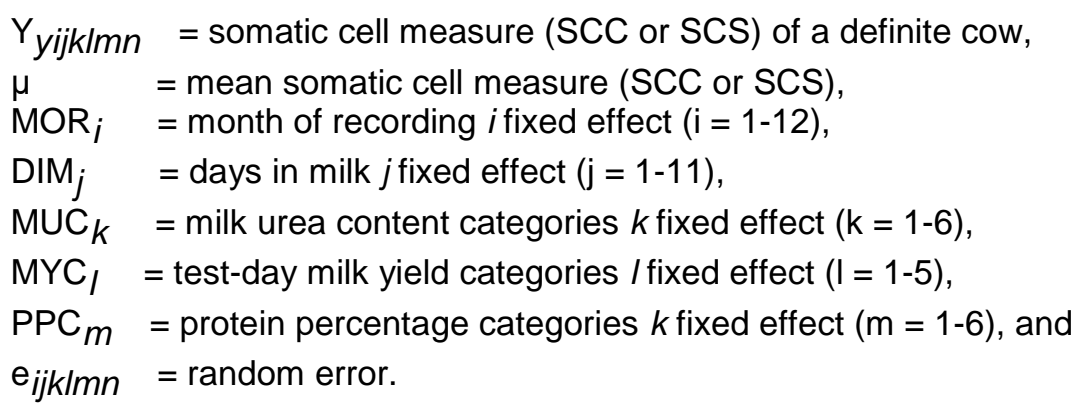

To study the importance of the recorded factors affecting total variation in milk urea content (MU), the following bivariate analysis of variance model was used:

$$
\mathrm{Y}_{i j k l m n}=\mu+\mathrm{MOR}_{i}+\mathrm{DIM}_{j}+\mathrm{SSC}_{k}+\mathrm{MYC}_{l}+\mathrm{PPC}_{m}+\mathrm{e}_{i j k l m n}
$$
where:

$\begin{array}{ll}Y_{i j k l m n} & =\text { test-day milk yield }(\text { TDM) or protein yield (PY) of a definite } \\ \text { cow, } & \\ \mu & =\text { mean MU or PY, } \\ \text { SSC }_{k} & =\text { somatic cell score categories } m \text { fixed effect }(k=1-5), \text { and }\end{array}$ The other definitions as mentioned in Equation 1.

The following bivariate analysis of variance model was used to study the importance of the recorded factors affecting total variation in test-day milk yield (TDM):

$$
\mathrm{Y}_{i j k / m n}=\mu+\mathrm{MOR}_{i}+\mathrm{DIM}_{j}+\mathrm{SSC}_{k}+\mathrm{MUC}_{l}+\mathrm{PPC}_{m}+\mathrm{e}_{i j k l m n}
$$
where:

$$
\begin{aligned}
& \mathrm{Y}_{i j k / m n}=\text { test-day milk yield }(\text { TDM) or protein yield (PY) of a definite } \\
& \text { cow, } \\
& \mu
\end{aligned}
$$

The other definitions as mentioned in Equations 1 and 2.

The following general linear fixed model was used to study the factors affecting the total variation in both protein percentage (PP) and protein yield (PY):

$$
\mathrm{Y}_{i j k l m n}=\mu+\mathrm{MOR}_{i}+\mathrm{DIM}_{j}+\mathrm{SSC}_{k}+\mathrm{MUC}_{l}+\mathrm{MYC}_{m}+\mathrm{e}_{i j k l m n}
$$

where:

$$
\begin{array}{ll}
\mathrm{y} i j k l m n & =\text { protein percentage or protein yield of a definite cow, } \\
\mu & =\text { mean PP or PY, }
\end{array}
$$

The other definitions as mentioned in Equations 1 and 2. 
Oudah, E. Z. M.

In another study by the author (Oudah, 2009), using the same data set, the phenotypic relationships including correlations and regressions coefficients and prediction equations were calculated and descriptive statistics (i.e. mean, SD, CV \%, minimum, and maximum) were also computed for TDM, PP, PY, SCC, SCS and MU.

\section{RESULTS AND DISCUSSION}

\section{Analysis of variance}

All of the variables included in the statistical models significantly $(\mathrm{P}<$ $0.05,0.01$ or 0.001$)$ influenced SCC, SCS, MU, TDM, PP and PY (R2 $=0.04$ to 0.84 ) (Table 3).

Table 3: Mean-square values of analysis of variance and level of significance of test-day traits as affected by non-genetic factors (fixed effects) along with descriptive statistics for models+

\begin{tabular}{|c|c|c|c|c|c|c|c|}
\hline \multirow{2}{*}{$\begin{array}{c}\text { Source of } \\
\text { variation }\end{array}$} & \multirow{2}{*}{ d.f } & \multicolumn{6}{|c|}{ Mean squares (Type III SS) } \\
\hline & & SCC & SCS & MU & TDM & PP & PY \\
\hline \multicolumn{8}{|c|}{ Fixed effects } \\
\hline MOR & 11 & $6445440 * * *$ & $39.3^{\star \star *}$ & $16446^{\star * *}$ & $2338^{\star * *}$ & $12.7^{* * *}$ & $0.65^{\star \star *}$ \\
\hline DIM & 10 & $5935563^{\star \star *}$ & $8.00^{\star *}$ & $2585^{\star * *}$ & $12256^{* * *}$ & $31.1^{* * *}$ & $0.63^{\star \star *}$ \\
\hline SSC & 4 & & & $2999^{* * *}$ & $2490^{* * *}$ & $6.76^{\star * *}$ & $0.03^{*}$ \\
\hline MUC & 5 & $10858217^{\star \star *}$ & $77.7^{\star \star *}$ & & $24322^{* \star *}$ & $1.59^{* * *}$ & $0.18^{\star \star \star}$ \\
\hline MYC & 4 & $32650278^{* * *}$ & $330^{* * *}$ & $62782^{\star * *}$ & & $25.2^{* * *}$ & $221^{* * *}$ \\
\hline PPC & 5 & $25263001^{* * *}$ & $213^{\star \star \star}$ & $2959^{\star \star \star}$ & $13058^{* * *}$ & & \\
\hline Residual & & 568605 & 3.238 & 106.697 & 44.872 & 0.0918 & 0.0109 \\
\hline \multicolumn{8}{|c|}{ Descriptive statistics for models used in the GLM procedure } \\
\hline $\begin{array}{l}\text { No. of } \\
\text { observations }\end{array}$ & & 22,877 & 22,877 & 22,146 & 22,146 & 22,146 & 22,146 \\
\hline Significance & & $P<0.0001$ & $P<0.0001$ & $P<0.0001$ & $P<0.0001$ & $P<0.0001$ & $P<0.0001$ \\
\hline R-square & & 0.04 & 0.07 & 0.18 & 0.36 & 32.0 & 84.0 \\
\hline Mean & & 410.3 & 3.75 & 32.3 & 22.1 & 3.40 & 0.739 \\
\hline Root MSE++ & & 754.1 & 1.80 & 10.3 & 6.70 & 0.30 & 0.104 \\
\hline $\mathrm{CV}, \%$ & & 183.8 & 48.0 & 32.0 & 30.3 & 8.92 & 14.1 \\
\hline
\end{tabular}

*: $\mathrm{P}<0.05,{ }^{\star \star}: \mathrm{P}<0.01,{ }^{\star \star \star}: \mathrm{P}<0.0001$

+ All abbreviations and units as mentioned in Table 2

++ Root mean-square error

Analysis of variance shows that MOR and DIM has highly significant $(P<0.01$ or 0.001$)$ effects on all studied traits. The coefficient of determination (R2) varied from $4 \%$ (for SCC) to $84 \%$ (for PY). In general, the magnitude of the effect of these factors including in the models in SCC, SCS and MUN was small. Only 4.0, 7.0 and $18.0 \%$ of the variation in SCC, SCS and MU values, respectively were explained by the factors studied. It is clear that there are other sources that account for most of the variation in SCC and MUN (including nutritional factors) which were not included in this study. Arunvipas et al. (2004) reported that only $18.9 \%$ of the variation in bulk tank MUN values was explained by the seasonal pattern and year of study. Stoop et al. (2007) stated that, in general, the magnitude of the effect of non-nutritional factors (DIM, Age at first calving, season of calving, herd) in MUN was small. Only $13.3 \%$ of the variation in MUN values was explained by the factors they studied. 
Coefficient of variation (CV \%) varied from $8.92 \%$ (for PP) to $183.8 \%$ (for SCC) (Table 3). Similar trends were found by Rekik et al. (2008) who reported that TDM, PY, and SCS were significantly affected by herd-test-day date, herd-calving year, calving to test-day interval, calving age, and calving to conception interval in the first and second lactations. The $\mathrm{R} 2$ varied from $41 \%$ to $69 \%$ for the studied traits, with SCS having the lowest R2 coefficients in all three lactations. Rodriguez-Zas et al. (2000) analyzed 2387 SCS records from 217 Holsteins and found that average SCC and standard deviation was 671,000 and $897,000 \mathrm{cells} / \mathrm{ml}$, respectively. They added that a few cows, with clinical mastitis symptoms, have very high levels of SCS, causing the average to be higher than the values usually associated to minor pathogens. Very high standard deviation for SCC was reported also by $\mathrm{Ng}$ Kwai-Hang et al. (1985) who found that SCC in terms of thousands per milliliter of milk was the most variable component with an overall mean of 297 and a standard deviation of more than twice this. The R2 for the GLM procedure that examined the relationship between the variables and $\mathrm{MU}$ was 0.47 using a large database $(n=1,279,600)$. The differences in the values of $\mathrm{R} 2$ and $\mathrm{CV} \%$ may be due to the different statistical analysis, breed, number of observations and/or fixed effects included in the statistical model.

\section{Associations among different variables}

\section{Effect of month of recording on studied traits}

Least squares means and standard errors of SCC, SCS, MU, TDM, PP and PY distributed monthly according to MOR and adjusted for the other factors included in the model are presented in Table 4 and Figures $1 \mathrm{a}$ and $\mathrm{b}$.

\section{Effect of MOR on SCC measures}

Generally, SCC was high during summer and fall seasons reached 408, 420, 495, 504 and 420 cell x 1000/ml for June, July, August, September and October, respectively. Meanwhile, SCC were low during winter and spring seasons reached $320,365,335,398$ and 384 cell $\times 1000 / \mathrm{ml}$ for December, January, February, March and April, respectively. The SCC reached the maximum level in September $(504,000 \mathrm{cell} / \mathrm{ml})$ associated to the lowest TDM $(19.9 \mathrm{~kg})$. The SCS followed the same trend of the SCC where maximum SCSs were in August (4.00) and September (3.91) and minimum SCSs were in December (3.50) and February (3.57) (Table 4 and Figure 1a). Reents et al. (1995) reported high SCS for the summer season. In addition, Coulon et al. (1996) analyzed 404 lactations of 208 dairy cows managed on an INRA Experimental Farm and found that SCC increased slightly during summer, independently of lactation stage. Rodriguez-Zas et al. (2000) analyzed 2387 SCS records from 217 Holsteins and found that lactations starting between October and December had the highest fall of SCS levels at the beginning of lactation, and the smallest increases thereafter. These results are in close agreement with the present results. Contrary, Rekik et al. (2008) reported that the calving season had no effects on SCS levels even though the summer season in Tunisia is characterized by its high temperature-humidity index.

\section{Effect of MOR on Mu}

Concentrations of MU were significantly $(P<0.001)$ associated with MOR (Table 4 and Figure 1b). The MU were at its highest levels in May and 
Oudah, E. Z. M.

September (least squares means $=36.1$ and $34.2 \mathrm{mg} / \mathrm{dl}$, respectively) and the lowest levels in February and March (least squares means $=29.1$ and $25.2 \mathrm{mg} / \mathrm{dl}$, respectively). There was significant difference between the highest and the lowest values in MU estimates by $10.9 \mathrm{mg} / \mathrm{dl}(30.2 \%)$. Several other researchers have reported high MUN during the summer $(\mathrm{Ng}$ Kwai-Hang et al., 1985; Carlsson et al., 1995; Ferguson et al., 1997; Godden et al., 2001a,b; Rajala-Schultz and Saville 2003; Hojman et al., 2004, 2005; Miglior et al., 2006 and Stoop et al., 2007). The present results in good agreement with the several previous studies. For example, $\mathrm{Ng}$-Kwai-Hang et al. (1985) studied the seasonal (monthly) variation of protein and non-protein nitrogenous (NPN) content of individual cow milk. They found that NPN content was lowest in March $(28 \mathrm{ml} / 100 \mathrm{ml})$ and tended to increase until October before dropping. Ferguson et al. (1997) reported that MU varied by season as follows: winter, $5.00 \pm 0.071$; spring, $5.35 \pm 0.075$; summer, $5.83 \pm$ 0.086; fall, $5.07 \pm 0.093$. In addition, Godden et al. (2001a) found that concentrations of MUN were highest from July to September and during the late summer season (July to September). Calberry (2003) stated that MUN concentrations may also increase in the spring as pastures become available. Rajala-Schultz and Saville (2003) showed that MUN concentrations were highest during summer and significantly lower in winter, spring and fall (2.5, 1.8 , and $2.8 \mathrm{mg} / \mathrm{dl}$ lower than in summer, respectively). In the high producing herds, the differences among seasons were much smaller, but significant for winter and spring and in fact, MUN concentrations were lowest during summer. They added that higher MUN values in summer in these herds could, however, be explained by cows having access to fresh pasture, which typically contains highly degradable protein and has high protein/energy ratio. This could also partially explain the high proportion of variability in MUN explained at test day level among these low producing herds. Hojman et al. (2004\&2005) reported that MU was significantly associated with month of the year; it was higher during the spring and summer months and lower in the cold season. Miglior et al. (2006), on Holstein cows, found that MUN concentration tended to be lower in winter and early summer, and higher in spring, late summer, and fall. Stoop et al. (2007) stated that the highest MUN values occurring in July and August. The total protein and true protein (mostly casein) in milk are lower during the summer months, while NPN, which includes urea, increases (Van Soest 1994; Carlsson et al., 1995 and Ferguson et al., 1997).

The variation in $\mathrm{MU}$ concentration may be attributed to changes in pasture protein and energy components from season to another. Australian spring pasture contained 20 to $30 \%$ crude protein but only 5 to $20 \%$ soluble carbohydrate. Thus, conditions were created for a high protein:energy ratio, which could result in elevated urea concentrations (Moller et al., 1993). However, other seasonally related factors that may contribute to the association between season and $\mathrm{MU}$ could include ambient temperature, humidity, and water intake (Godden et al., 2001b). Lower MUN concentrations in summer than in winter and spring for high producing herds could be related to lower dry matter intake due to the heat and thus lower protein intake in summer (Rajala-Schultz and Saville 2003). The seasonal 
variation in $\mathrm{MU}$ also may be attributed to feed changes associated with season, such as the use of corn silages, fresh silage, and pasture, are likely to influence MUN values as reported by Arunvipas et al. (2004). They added that during the pasture season, herds had a higher bulk tank-MUN than during the non-pasture period, particularly during the mid and late pasture season.

\section{Effect of MOR on milk production traits}

Test-day milk yield, PP and PY were significantly $(P<0.001)$ associated with MOR (Table 4 and Figures $1 \mathrm{a}$ and $\mathrm{b}$ ). It could be noticed, in general, that milk production traits (TDM, PP and PY) in its highest levels in fall (November) and in its lowest levels in summer months (August and September). Least squares means of TDM, adjusted for the other factors, during September month the lowest $(19.9 \mathrm{~kg} / \mathrm{day})$ comparing with the other months. Test-day milk yield increased to the maximum level in November $(23.4 \mathrm{~kg} / \mathrm{day})$. Milk protein yield followed the same trend of TDM where the highest PY level was in November $(0.805 \mathrm{~kg} /$ day $)$ followed by October $(0.800$ $\mathrm{kg} /$ day $)$ and the lowest PY was in August $(0.742 \mathrm{~kg} /$ day $)$ followed by September $(0.751 \mathrm{~kg} /$ day $)$. Generally, PY was high during the months of fall (October-December) ranged between 0.781 to $0.805 \mathrm{~kg} / \mathrm{day}$ and low level during the summer months (July-September) ranged between 0.742 to 0.754 $\mathrm{kg} /$ day. Milk protein percent was in its highest level in November $(3.56 \%)$ and the lowest level in August (3.27\%). Ng-Kwai-Hang et al. (1985) noticed that seasonal (monthly) variation of protein and NPN content of individual cow milk were high in January, decreased gradually reaching minimum in July, after which they increased to peak in October.

\section{Effect of days in milk on studied traits}

Least squares means of SCC, SCS, MU, milk production traits (TDM, PP and PY) as affected by DIM categories are given in Table 5 and Figures 2 $a$ and $b$.

\section{Effect of DIM on SCC measures}

Somatic cell count slight increased in the first four months of lactation (444, 465, 467 and 469 cell $\times 1000 / \mathrm{ml}$, respectively) then declined gradually to the end of lactation (decreased from 442,000 in the fifth month to 309,000 cell $/ \mathrm{ml}$ in the tenth month of lactation). The gradual increase in SCC in months 2, 3 and 4 of lactation was only two millions cell $/ \mathrm{ml}$. least square mean of SCS in the first month of lactation was 3.65 slightly decreased to 3.60 in the $2^{\text {nd }}$ month then increased gradually from the $3^{\text {rd }}$ month (3.69) to reach the maximum in the $7^{\text {th }}$ month (3.79) then declined to the end of lactation (3.6) (Table 5 and Figure 2a). The range between the maximum and minimum value of SCC was $160,000 \mathrm{cell} / \mathrm{ml}$ (34\% of the maximum value). Similar results were found by Spicer et al. (2000) who reported that weekly SCC did not change ( $P>0.1)$ between week 1 and 12 of lactation and averaged 430,000 $\pm 157,000$. Wiggans and Shook (1987) noticed that after the beginning of lactation, SCS decreases to a minimum at around 60 days post-calving and increases thereafter. Other studies also (Bodoh et al., 1976; Kennedy et al., 1982 and Emanuelson and Persson, 1984) reported that stage of lactation has an effect on sample day SCC, and SCC declines 
Oudah, E. Z. M.

rapidly until the $2^{\text {nd }}$ month of lactation before slowly rising to dry off. These results are in good agreement with those of the present study. Variation in the shape and level of the SCS pattern is related to lactation number (Wiggans and Shook 1987), to udder infection status (Sheldrake et al., 1983) and to individual cows (Rodriguez-Zas et al., 2000). Atakan (2008) and Rekik et al. (2008) confirmed the significant effect of DIM on SCC measures reported in the present study also. Atakan (2008) stated that lactation month had a significant $(P<0.01)$ effect on SCC in milk. Rekik et al. (2008) also found that days in milk, calving age, and calving to conception interval were all together important sources of variation $(p<0.05)$ for SCS. On the other hand, Coulon et al. (1996) studied the changes in somatic cell count in 404 lactations of 208 dairy cows and found that on average, SCC was minimal in the second month of lactation $(50,000 \mathrm{cells} / \mathrm{ml})$ and maximal in late lactation $(200,000 \mathrm{cells} / \mathrm{ml})$. It is worth to mention that only lactations free of clinical mastitis were included in the study of Coulon et al. (1996). Wicks and Leaver (2006) found that there was an increase in monthly SCC with increasing stage of lactation in Holstein-Friesian cows. They attributed the fall in SCC during the first three months of lactation probably to a dilution effect as daily milk yield increased towards peak. The progressive rise from 3 months to the end of lactation may be attributed to increased somatic cells and decreased daily milk yield. In Canada, Dürr et al. (2008) concluded that daily milk losses caused by changes in LnSCC depend on breed, parity and stage of lactation, and ignoring these factors leads to significant errors in estimating losses associated to subclinical mastitis.

\section{Effect of DIM on Mu}

The MU increased steadily with advancing of lactation period until the $7^{\text {th }}$ month of lactation reached $33.3 \pm 0.27 \mathrm{mg} / \mathrm{dl}$. The concentration of $\mathrm{MU}$ was significantly $(\mathrm{P}<0.001)$ lower during the first 30 -DIM category $(29.7 \pm 0.30$ $\mathrm{mg} / \mathrm{dl}$ ) compared with all other DIM categories except for MU concentration in the $2^{\text {nd }}$ month of lactation $(30.0 \pm 0.28 \mathrm{mg} / \mathrm{dll})$ the difference was not significant. From the results given in Table 5 and Figure 2b, it could be noticed that the MU during the early lactation (first 90-days) were lower (ranged between 29.7 to $31.1 \mathrm{mg} / \mathrm{dl}$ ) than that of the mid location (90-210 days) (ranged between 32.3 to $33.3 \mathrm{mg} / \mathrm{dl}$ ). In addition, the differences in $\mathrm{MU}$ among the months from $4^{\text {th }}$ to $10^{\text {th }}$ were not significant. A number of studies (Carlsson et al., 1995; Spicer et al., 2000; Godden et al., 2001a,b; Johnson and Young 2003; Rajala-Schultz and Saville 2003; Wood et al., 2003; Hojman et al., 2004\&2005 and Stoop et al., 2007) reported significant effects of DIM on MUN, but the direction of the effect was inconsistent. Many studies have reported lower MUN during the first month of lactation than later (Bruckental et al., 1980; DePeters and Ferguson 1992;; Carlsson et al., 1995; Arunvipas et al., 2003, 2004 and Stoop et al., 2007). However, Faust et al., (1997) and Schepers and Meijer (1998) found no variation in MUN by stages of lactation. 
J. Agric. Sci. Mansoura Univ., 34 (9), September, 2009

$4+5$

9433 
Oudah, E. Z. M.

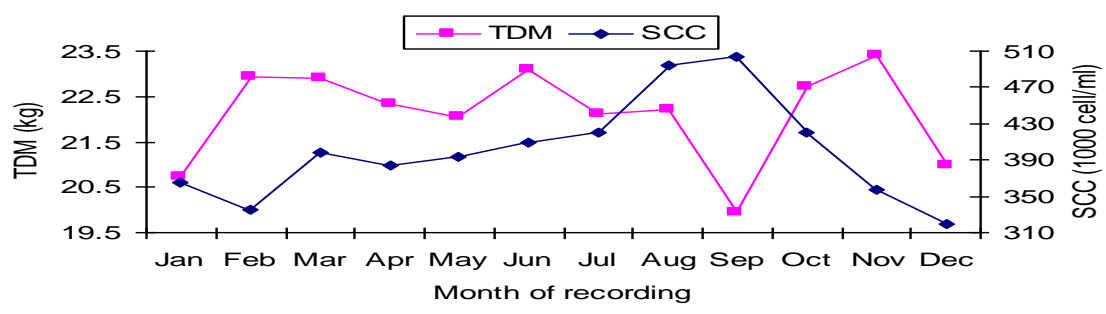

Figure 1a: TDM and SCC by month of recording

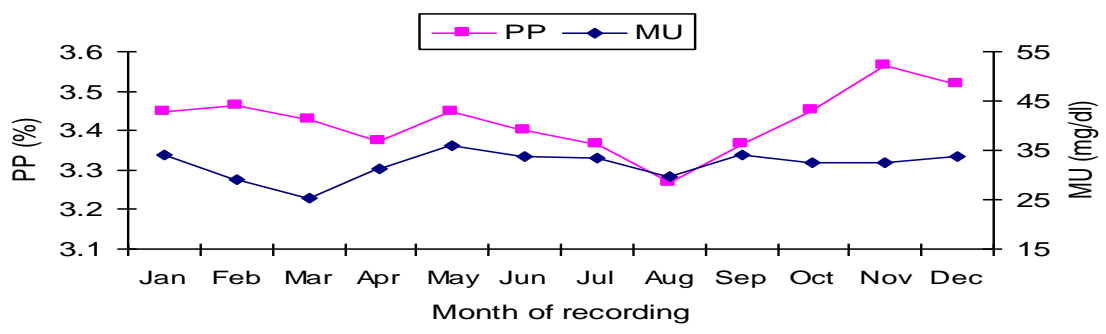

Figure 1b: $\mathrm{pp}$ and $\mathrm{MU}$ by month of recording

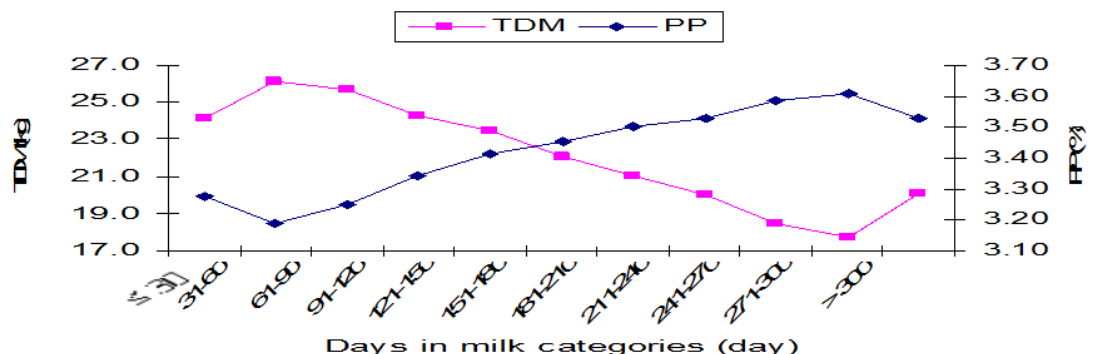

Figure 2a: TDM and PP by days in milk

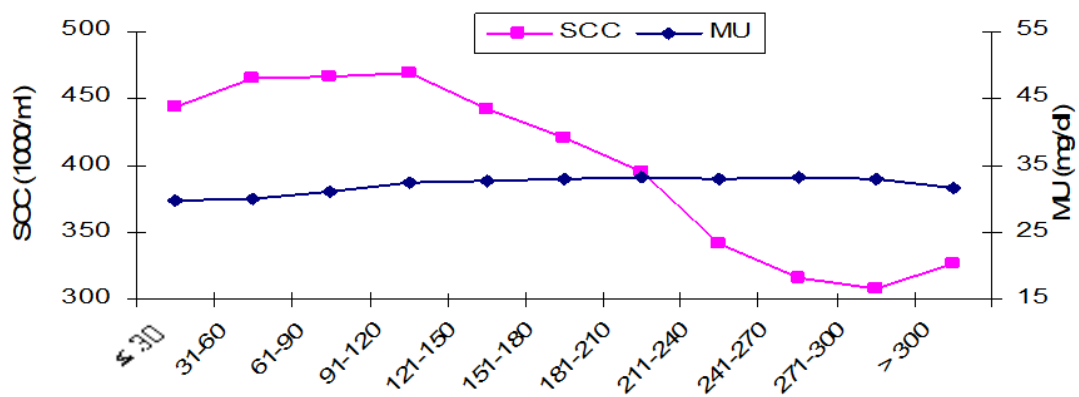

Days in milk categories (day)

Figure 2b: SCC and MU by days in milk 
Rajala-Schultz and Saville (2003) noticed that MUN concentrations in Ohio dairy herds were lowest during the first month of lactation. Johnson and Young (2003) found that MUN concentrations were lower during the first 30 DIM compared with all other DIM categories for both Holstein and Jersey cows. They added that although it can be speculated that the lower MUN concentrations might be related to lower dry matter intake or possibly consumption of a ration with a different composition than after 30 DIM. Similar results were found also by Arunvipas et al. (2003) who reported that The MUN was lower during the first month of lactation. This observation agrees with the finding of the present study. The present findings are also in accordance with reports by Carlsson et al. (1995) who found that MU was lowest immediately after calving, increased, reached a maximum between 3 and 6 mo of lactation, and then slowly declined. Similar results were found also by Spicer et al. $(2000)$ who noticed that MU increased $(P<0.05)$ during early lactation, plateauing after wk 3 . They concluded that week of lactation should be considered when interpreting MUN values. Godden et al. (2001a) found that concentrations of MUN were highest in cows between 60-150 days in milk. Milk urea nitrogen was lowest in first lactation cows as well as cows in their first 60 days in milk or after 150 days in milk. Wood et al. (2003) found that herd-test-day effects had the most significant impact on MUN. They added that effects of stage of lactation were also important, and MUN levels tended to increase from the time of peak yield until the end of lactation. Hojman et al. (2004) noticed that on the second monthly test day, MU concentration was at its lowest level (least squares mean $=13.5 \mathrm{mg}$ of $\mathrm{MUN} / \mathrm{dL}$ ). From then on, MU level progressively increased until 300 DIM (least squares mean $=14.7 \mathrm{mg}$ of $\mathrm{MUN} / \mathrm{dL}$ ) and then leveled off and decreased toward the end of lactation. The same authors (Hojman et al., 2004) in another study (Hojman et al., 2005) found a positive association between DIM and $\mathrm{MU}$ concentration and stated that $\mathrm{MU}$ is lowest immediately after calving, increases to a maximum concentration between the $3^{\text {rd }}$ and $6^{\text {th }}$ months of lactation, and then slowly declines. Stoop et al. (2007) found a peak between the second and third month of lactation and a slight decrease in MUN with advancing DIM. The previous results in good agreement with those reported in the present study.

Changes in ration nutrient composition or feeding programs that occur among different stages of lactation could contribute to the variation observed in MU. There may also be physiological differences that could affect MU. For example, rumen microbial adaptation, and rumen absorptive capacity could contribute to differences in MU at different stages of lactation 
Oudah, E. Z. M.

(Godeen et al., 2001a). On the other hand, Schepers and Meijer (1998) found no association between stage of lactation and MU when feeding trials were controlled for nutritional factors. However, the authors stated that because the nutritional variables they looked at were not statistically independent, the effect of DIM was probably included indirectly through the nutritional factors. This suggests that non-nutritional factors are of minor importance in explaining the association between MU and stage of lactation. Carlsson et al. (1995) observed the same with cows that were housed inside (i.e., were not grazing), especially high producing cows have difficulty in meeting their requirements for energy, and they are in a negative energy balance at the beginning of lactation (Carlsson et al., 1995). Lower MUN concentrations at the beginning of lactation could be related to and explained by the inability of cows to ingest sufficient amount of feed, which could lead to, or be result of, suboptimal function of the ruminal flora (Carlsson et al., 1995).

\section{Effect of DIM on milk production traits}

Least squares means and standard errors of TDM, PP and PY by DIM are given in Table 5 and illustrated in Figure 2a. Test-day milk yield reached the peak in the $2^{\text {nd }}$ month of lactation $(26.2 \pm 0.19 \mathrm{~kg})$ then decreased gradually to the end of lactation. Protein percentage followed opposite trend to that of TDM, where PP declined to the lowest level in the second month of lactation $(3.19 \pm 0.008 \%)$ then increased gradually and steadily to the end of lactation. This reversible trend between TDM and PP reflect the known negative relationship between them. Protein yield followed the same trend of PP ranged between $0.737 \mathrm{~kg}$ ( $2^{\text {nd }}$ month) to $0.792 \mathrm{~kg}$ ( $8^{\text {th }}$ month) with no significant changed between most months of lactation.

Effects of DIM on milk yield are well documented. In general, daily milk yield increases to peak a few weeks after calving (the $2^{\text {nd }}$ month of lactation) and then gradually declines to dry off. Such a trend is exactly what one would expect from the study of the lactation curve (milk yield increases up to a peak and then decreases steadily up to the end of the lactation). Wood (1976) found that fat and protein percentages declined to a trough early in lactation (wk 8 and 11 for fat and protein percentage, respectively) and then gradually increased to dry off. Fat and protein yields reached an early peak (by wk 3 ) and then declined but more slowly than did milk. Similar results were found also by several studies. Spicer et al. (2000) found that milk protein level decreased $(\mathrm{P}<.05)$ between wk 1 and 3 postpartum and remained constant between wk 4 and 12 .

\section{Association between SCC and milk production traits}

Least squares means and standard errors of TDM, PP and PY by

somatic cell score categories are given in Table 6 and Figures $3 a$ and $b$.

\section{Effect of DIM on SCC measures}

Somatic cell count slight increased in the first four months of lactation (444, 465, 467 and 469 cell $\times 1000 / \mathrm{ml}$, respectively) then declined gradually to the end of lactation (decreased from 442,000 in the fifth month to 309,000 cell $/ \mathrm{ml}$ in the tenth month of lactation). The gradual increase in SCC in months 2, 3 and 4 of lactation was only two millions cell/ml. least square 
mean of SCS in the first month of lactation was 3.65 slightly decreased to 3.60 in the $2^{\text {nd }}$ month then increased gradually from the $3^{\text {rd }}$ month (3.69) to reach the maximum in the $7^{\text {th }}$ month (3.79) then declined to the end of lactation (3.6) (Table 5 and Figure 2a). The range between the maximum and minimum value of SCC was $160,000 \mathrm{cell} / \mathrm{ml}$ (34\% of the maximum value). Similar results were found by Spicer et al. (2000) who reported that weekly SCC did not change $(P>0.1)$ between week 1 and 12 of lactation and averaged 430,000 $\pm 157,000$. Wiggans and Shook (1987) noticed that after the beginning of lactation, SCS decreases to a minimum at around 60 days post-calving and increases thereafter. Other studies also (Bodoh et al., 1976; Kennedy et al., 1982 and Emanuelson and Persson 1984) reported that stage of lactation has an effect on sample day SCC, and SCC declines rapidly until the $2^{\text {nd }}$ month of lactation before slowly rising to dry off. These results are in good agreement with those of the present study. Variation in the shape and level of the SCS pattern is related to lactation number (Wiggans and Shook 1987), to udder infection status (Sheldrake et al., 1983) and to individual cows (Rodriguez-Zas et al., 2000). Atakan (2008) and Rekik et al. (2008) confirmed the significant effect of DIM on SCC measures reported in the present study also. Atakan (2008) stated that lactation month had a significant $(P<0.01)$ effect on SCC in milk. Rekik et al. (2008) also found that days in milk, calving age, and calving to conception interval were all together important sources of variation $(\mathrm{p}<0.05)$ for SCS. On the other hand, Coulon et al. (1996) studied the changes in somatic cell count in 404 lactations of 208 dairy cows and found that on average, SCC was minimal in the second month of lactation $(50,000 \mathrm{cells} / \mathrm{ml})$ and maximal in late lactation $(200,000 \mathrm{cells} / \mathrm{ml})$. It is worth to mention that only lactations free of clinical mastitis were included in the study of Coulon et al. (1996). Wicks and Leaver (2006) found that there was an increase in monthly SCC with increasing stage of lactation in Holstein-Friesian cows. They attributed the fall in SCC during the first three months of lactation probably to a dilution effect as daily milk yield increased towards peak. The progressive rise from 3 months to the end of lactation may be attributed to increased somatic cells and decreased daily milk yield. In Canada, Dürr et al. (2008) concluded that daily milk losses caused by changes in LnSCC depend on breed, parity and stage of lactation, and ignoring these factors leads to significant errors in estimating losses associated to subclinical mastitis.

Table 6: Least squares means (LSM) and standard errors (SE) of milk urea content (MU, mg/dl), test-day milk yield (TDM, kg), protein percentage (PP\%) and protein yield (PY, kg) by somatic cell score (SCS) categories (C)

\begin{tabular}{|c|c|c|c|c|c|c|c|c|c|c|c|}
\hline \multirow{3}{*}{ C } & \multirow{3}{*}{ SCS } & \multicolumn{2}{|c|}{ Observations } & \multicolumn{8}{|c|}{ Trait } \\
\hline & & \multirow{2}{*}{ No. } & \multirow{2}{*}{$\%$} & \multicolumn{2}{|c|}{$\overline{M U}$} & \multicolumn{2}{|c|}{ TDM } & \multicolumn{2}{|c|}{ PP } & \multicolumn{2}{|c|}{ PY } \\
\hline & & & & LSM & SE & LSM & SE & LSM & SE & LSM & SE \\
\hline 1 & $0-3$ & 10249 & 46.26 & 33.2 & 0.18 & $23.2 \mathrm{a}$ & 0.12 & $3.37 a$ & 0.01 & $0.769 a$ & 0.002 \\
\hline 2 & 4 & 4664 & 21.05 & $32.6 a$ & 0.21 & $22.4 b$ & 0.14 & $3.41 b$ & 0.01 & $0.773 a$ & 0.002 \\
\hline 3 & 5 & 3291 & 14.86 & $32.2 a$ & 0.23 & 22.0bf & 0.16 & $3.42 b$ & 0.01 & $0.771 \mathrm{a}$ & 0.002 \\
\hline 4 & 6 & 2001 & 9.03 & $31.9 a$ & 0.27 & $21.8 \mathrm{cf}$ & 0.18 & $3.43 b$ & 0.01 & $0.768 a$ & 0.003 \\
\hline
\end{tabular}


Oudah, E. Z. M.

$\begin{array}{llllllllllll}5 & 7-9 & 1948 & 8.79 & 30.6 & 0.28 & 21.2 \mathrm{c} & 0.18 & 3.48 \mathrm{c} & 0.01 & 0.775 \mathrm{a} & 0.003\end{array}$

* Least squares Means within the same column with similar superscript are not significantly $(P>0.05)$ different

\section{Effect of DIM on Mu}

The MU increased steadily with advancing of lactation period until the $7^{\text {th }}$ month of lactation reached $33.3 \pm 0.27 \mathrm{mg} / \mathrm{dl}$. The concentration of $\mathrm{MU}$ was significantly $(P<0.001)$ lower during the first 30 -DIM category $(29.7 \pm 0.30$ $\mathrm{mg} / \mathrm{dl}$ ) compared with all other DIM categories except for MU concentration in the $2^{\text {nd }}$ month of lactation $(30.0 \pm 0.28 \mathrm{mg} / \mathrm{dl})$ the difference was not significant. From the results given in Table 5 and Figure $2 b$, it could be noticed that the MU during the early lactation (first 90-days) were lower (ranged between 29.7 to $31.1 \mathrm{mg} / \mathrm{dl}$ ) than that of the mid location (90-210 days) (ranged between 32.3 to $33.3 \mathrm{mg} / \mathrm{dl}$ ). In addition, the differences in $\mathrm{MU}$ among the months from $4^{\text {th }}$ to $10^{\text {th }}$ were not significant. A number of studies (Carlsson et al., 1995; Spicer et al., 2000; Godden et al., 2001a,b; Johnson and Young 2003; Rajala-Schultz and Saville 2003; Wood et al., 2003; Hojman et al., 2004\&2005 and Stoop et al., 2007) reported significant effects of DIM on MUN, but the direction of the effect was inconsistent.

Many studies have reported lower MUN during the first month of lactation than later (Bruckental et al., 1980; DePeters and Ferguson 1992; Carlsson et al., 1995; Arunvipas et al., 2003, 2004 and Stoop et al., 2007). However, Faust et al. (1997) and Schepers and Meijer (1998) found no variation in MUN by stages of lactation. Rajala-Schultz and Saville (2003) noticed that MUN concentrations in Ohio dairy herds were lowest during the first month of lactation. Johnson and Young (2003) found that MUN concentrations were lower during the first 30 DIM compared with all other DIM categories for both Holstein and Jersey cows. They added that although it can be speculated that the lower MUN concentrations might be related to lower dry matter intake or possibly consumption of a ration with a different composition than after $30 \mathrm{DIM}$. Similar results were found also by Arunvipas et al. (2003) who reported that The MUN was lower during the first month of lactation. This observation agrees with the finding of the present study. The present findings are also in accordance with reports by Carlsson et al. (1995) who found that MU was lowest immediately after calving, increased, reached a maximum between 3 and 6 mo of lactation, and then slowly declined. Similar results were found also by Spicer et al. (2000) who noticed that MU increased $(\mathrm{P}<0.05)$ during early lactation, plateauing after wk 3 . They concluded that week of lactation should be considered when interpreting MUN values. Godden et al. (2001a) found that concentrations of MUN were highest in cows between $60-150$ days in milk. Milk urea nitrogen was lowest in first lactation cows as well as cows in their first 60 days in milk or after 150 days in milk. Wood et al. (2003) found that herd-test-day effects had the most significant impact on MUN. They added that effects of stage of lactation were also important, and MUN levels tended to increase from the time of peak yield until the end of lactation. Hojman et al. (2004) noticed that on the second monthly test day, MU concentration was at its lowest level (least squares mean $=13.5 \mathrm{mg}$ of $\mathrm{MUN} / \mathrm{dL}$ ). From then on, MU level progressively 
increased until 300 DIM (least squares mean $=14.7 \mathrm{mg}$ of $\mathrm{MUN} / \mathrm{dL}$ ) and then leveled off and decreased toward the end of lactation. The same authors (Hojman et al., 2004) in another study (Hojman et al., 2005) found a positive association between DIM and MU concentration and stated that MU is lowest immediately after calving, increases to a maximum concentration between the $3^{\text {rd }}$ and $6^{\text {th }}$ months of lactation, and then slowly declines. Stoop et al. (2007) found a peak between the second and third month of lactation and a slight decrease in MUN with advancing DIM. The previous results in good agreement with those reported in the present study.

Changes in ration nutrient composition or feeding programs that occur among different stages of lactation could contribute to the variation observed in MU. There may also be physiological differences that could affect MU. For example, rumen microbial adaptation, and rumen absorptive capacity could contribute to differences in $\mathrm{MU}$ at different stages of lactation (Godeen et al., 2001a). On the other hand, Schepers and Meijer (1998) found no association between stage of lactation and MU when feeding trials were controlled for nutritional factors. However, the authors stated that because the nutritional variables they looked at were not statistically independent, the effect of DIM was probably included indirectly through the nutritional factors. This suggests that non-nutritional factors are of minor importance in explaining the association between $\mathrm{MU}$ and stage of lactation. Carlsson et al. (1995) observed the same with cows that were housed inside (i.e., were not grazing), especially high producing cows have difficulty in meeting their requirements for energy, and they are in a negative energy balance at the beginning of lactation (Carlsson et al., 1995). Lower MUN concentrations at the beginning of lactation could be related to and explained by the inability of cows to ingest sufficient amount of feed, which could lead to, or be result of, suboptimal function of the ruminal flora (Carlsson et al., 1995).

\section{Effect of DIM on milk production traits}

Least squares means and standard errors of TDM, PP and PY by DIM are given in Table 5 and illustrated in Figure 2a. Test-day milk yield reached the peak in the $2^{\text {nd }}$ month of lactation $(26.2 \pm 0.19 \mathrm{~kg})$ then decreased gradually to the end of lactation. Protein percentage followed opposite trend to that of TDM, where PP declined to the lowest level in the second month of lactation $(3.19 \pm 0.008 \%)$ then increased gradually and steadily to the end of lactation. This reversible trend between TDM and PP reflect the known negative relationship between them. Protein yield followed the same trend of PP ranged between $0.737 \mathrm{~kg}$ ( $2^{\text {nd }}$ month) to $0.792 \mathrm{~kg}$ ( $8^{\text {th }}$ month) with no significant changed between most months of lactation.

Effects of DIM on milk yield are well documented. In general, daily milk yield increases to peak a few weeks after calving (the $2^{\text {nd }}$ month of lactation) and then gradually declines to dry off. Such a trend is exactly what one would expect from the study of the lactation curve (milk yield increases up to a peak and then decreases steadily up to the end of the lactation). Wood (1976) found that fat and protein percentages declined to a trough early in lactation (wk 8 and 11 for fat and protein percentage, respectively) and then gradually increased to dry off. Fat and protein yields reached an 
Oudah, E. Z. M.

early peak (by wk 3 ) and then declined but more slowly than did milk. Similar results were found also by several studies. Spicer et al. (2000) found that milk protein level decreased $(\mathrm{P}<.05)$ between wk 1 and 3 postpartum and remained constant between wk 4 and 12 .

Association between SCC and milk production traits

Least squares means and standard errors of TDM, PP and PY by somatic cell score categories are given in Table 7 and Figures $3 a$ and b.

Table 7: Least squares means (LSM) and standard errors (SE) of milk urea content (MU, $\mathrm{mg} / \mathrm{dl}$ ), test-day milk yield (TDM, $\mathrm{kg}$ ), protein percentage (PP\%) and protein yield (PY, $\mathrm{kg}$ ) by somatic cell score (SCS) categories (C)

\begin{tabular}{|c|c|c|c|c|c|c|c|c|c|c|c|}
\hline \multirow{3}{*}{ C } & \multirow{3}{*}{ SCS } & \multicolumn{2}{|c|}{ Observations } & \multicolumn{8}{|c|}{ Trait } \\
\hline & & \multirow{2}{*}{ No. } & \multirow{2}{*}{$\%$} & \multicolumn{2}{|c|}{ MU } & \multicolumn{2}{|c|}{ TDM } & \multicolumn{2}{|c|}{ PP } & \multicolumn{2}{|c|}{ PY } \\
\hline & & & & LSM & SE & LSM & SE & LSM & SE & LSM & SE \\
\hline 1 & $0-3$ & 10249 & 46.26 & 33.2 & 0.18 & $23.2 \mathrm{a}$ & 0.12 & $3.37 a$ & 0.01 & $0.769 a$ & 0.002 \\
\hline 2 & 4 & 4664 & 21.05 & $32.6 a$ & 0.21 & $22.4 b$ & 0.14 & $3.41 b$ & 0.01 & $0.773 a$ & 0.002 \\
\hline 3 & 5 & 3291 & 14.86 & $32.2 \mathrm{a}$ & 0.23 & $22.0 \mathrm{bf}$ & 0.16 & $3.42 \mathrm{~b}$ & 0.01 & $0.771 \mathrm{a}$ & 0.002 \\
\hline 4 & 6 & 2001 & 9.03 & $31.9 a$ & 0.27 & $21.8 \mathrm{cf}$ & 0.18 & $3.43 b$ & 0.01 & $0.768 a$ & 0.003 \\
\hline 5 & $7-9$ & 1948 & 8.79 & 30.6 & 0.28 & $21.2 \mathrm{c}$ & 0.18 & $3.48 c$ & 0.01 & $0.775 a$ & 0.003 \\
\hline
\end{tabular}

Least squares means and standard errors of SCC and SCS by PP categories are given in Table 8 and Figures $5 a$ and $b$. Test-day milk yield was unfavourably affected by high SCS recorded in the same test-day. Test-day milk yield, adjusted for the other variables, significantly $(\mathrm{P}<0.001)$ decreased from $23.2 \pm 0.12 \mathrm{~kg}$ in the first SCS category (SCS $0-3$, considered uninfected cows with mastitis) to $21.2 \pm 0.08 \mathrm{~kg}$ in the fifth (last) SCS category (SCS 7-9 considered clinically infected cows with mastitis). This range between the first and the last SCS categories in TDM equal $2 \mathrm{~kg}$ milk in test-day milking and represents $8.62 \%$ of the highest category (Table 6). Meanwhile, PP, adjusted for the other variables, significantly $(P<0.001)$ increased from $3.37 \pm 0.01$ to $3.48 \pm 0.01 \%$, for the $1^{\text {st }}$ and last SCS categories, respectively. Direct losses in milk and protein yields from increased SCS are important. The negative relationship between SCS and milk yield has been referred to as "milk loss". Another explanation concerning the negative relationship between milk yield and SCC hypothesize that part of the decrease of the milk production is due to increased demand for energy of the immune system against the infection, decreased appetite associated with any inflammation and lowered food intake due to pain and decreased movements. These results are in accordance with findings of Raubertas and Shook (1982); Jones et al. (1984); Fetrow et al. (1991) and Rekik et al. (2008). Raubertas and Shook (1982) estimated that each unit increase in lactation SCS was associated with losses of 91 and $181 \mathrm{~kg}$ of milk during parities 1 and 2, respectively. Fetrow et al. (1991) found that the effect of increased SCC during second lactation on third-lactation milk yield was significant $(P<0.04)$ but only 20 to $30 \%$ as large as the direct effect of SCC during third lactation. Rekik et al. (2008) found that TDM was unfavourably affected by high SCS recorded in the same test-day and the 
reduction in milk production from increased SCS varied from 0.23 to $1.76 \mathrm{~kg}$. Additionally, Miller et al. (2004) reported that the relationship between milk yield and SCC might overestimate true milk loss due to mastitis. They added that three important aspects concerning interpretation of the relationship between milk yield and SCC are: 1) interpretation of variation among SCC at low levels, 2) presence of a "dilution effect" because of relatively constant SCC throughout lactation if no infection is present, and 3) compensation by uninfected quarters for mastitic quarters. Some studies also showed that the increased SCS before first service affects negatively leutinizing hormone (LH) pulses, which may delay ovulation (Barker et al., 1998). Likewise, increased SCS because of mastitis infection may increase prostaglandin hormone (PGF2 $\alpha$ ) concentration leading to abortion and consequently lengthens the interval between calving and conception (Barker et al., 1998). Furthermore, milk with high SCC has its coagulation properties compromised and the efficiency of cheese production reduced (Ikonen et al., 2004).

Table 6 shows that, from 22153 test-day records, 10249 (46.3\%) were uninfected (less than $140,000 \mathrm{cell} / \mathrm{ml}$ ), meanwhile, 1948 test-day records $(8.79 \%)$ were infected (more than 1,130,000). The intermediate scores between the two groups (categories 2, 3 and 4) represent the rest of the test-day records (44.9\%), in spite of Jones et al. (1984) pointed out that the data of Dairy Herd Improvement (DHI) suggest that SCC of 200 to 400 cell $x 1000 / \mathrm{ml}$ are associated with lower milk yields and greater infection rates. Koivula et al. (2005) considered that cows have scores greater than 5.5 (560,000 cells $/ \mathrm{ml})$, are clinically infected. Also, Ruegg et al. (2008) using the data of DHI, suggested that quarters with SCC $\geq 200,000 \mathrm{cells} / \mathrm{ml}$ at both dry-off and post-calving are at DIM proportion of cows without a clinical case greater risk for clinical mastitis and are more likely to be subclinically infected at the first DHIA test of the subsequent lactation. By comparing herd somatic cell values to benchmark values, producers can identify problems and set goals for improvement. Therefore, tests for the detection of mastitis should be set up for cattle herds, especially the genetic correlations between clinical mastitis and SCS are greater than 0.60 (Carlén et al., 2004 and Koivula et al., 2005).

On the other hand, monitoring SCC and SCS by TDM (Table 7) and PP (Table 8) categories, there are linear and negative relationships between TDM and each of SCC and SCS. From Table 7, It could be noticed that with increasing TDM categories from 1-5, SCC significantly $(P<0.01)$ decreased from $570 \pm 16.7$ in the first category ( $\leq 15 \mathrm{~kg} / \mathrm{TDM})$ to $330 \pm 17.4 \mathrm{cell} \times 1000 / \mathrm{ml}$ in the fifth (last) category ( $>30 \mathrm{~kg} / \mathrm{TDM})$. The range between the first and the last TDM categories in SCC equal 240 cell $\times 1000 / \mathrm{ml}$ milk and represents $42 \%$ the highest category. This means that with increasing SCC in milk, TDM in the same milking decrease. SCS followed the same trend of SCC, where SCS decreased from $4.25 \pm 0.04$ to $3.49 \pm 0.04$ in the first and fifth TDM categories, respectively. This range between the first and the last TDM categories in SCS equal 0.76 and represents $17.9 \%$ of the highest category (Table 7).

From Table 8, it could be noticed that there are linear and positive relationships between PP and each of SCC or SCS in the same milking. 
Oudah, E. Z. M.

Test-day milk with less than $3 \%$ PP (first PP category) had only $267 \pm 19.1$ cell $\mathrm{x} 1000 / \mathrm{ml} \mathrm{SCC}$ and $3.28 \pm 0.05$ SCS, meanwhile test-day milk with $>3.8 \%$ PP (sixth or last category) had $577 \pm 19.2$ cell $x 1000 / \mathrm{ml} \mathrm{SCC}$ and $4.18 \pm 0.05$ SCS. The range between the two categories in SCC was 310 cell $\times 1000 / \mathrm{ml}$ and represents $53.7 \%$ of the highest category. Some studies (Shuster et al., 1991; Auldist et al., 1995 and Auldist and Hubble 1998) reported that during mastitis, there is an increase in milk proteins and that has been attributed to the influx of blood-borne proteins (such as serum albumin, immunoglobulins, the minor serum proteins, transferring á-macroglobulin into the milk coupled with a decrease in caseins. According to Auldist et al. (1995) and Auldist and Hubble (1998), this increase in proteins of blood serum origin during mastitis is possibly due to a disruption to the integrity of the mammary epithelia by microbial toxins and opening of the tight junctions. Auldist and Hubble (1998) continue that the decrease in casein concentrations during mastitis is largely due to post-secretory degradation of casein by proteinases originating from mastitis-causing organisms, leucocytes or the blood and in part to a reduction in the synthesis and secretion of casein because of physical damage to the mammary epithelial cells by microbial toxins during mastitis. Wicks and Leaver (2006) found that in cows of greater than parity two, a negative correlation between actual milk production and SCC showed that SCC declined as milk yield increased. This decrease in SCC with milk production may not represent a change in the number of cells shed, but a dilution effect (Miller et al., 1983) or alternatively as a result of mastitis, and the inflammatory responses associated with mastitis, the secretion and removal of milk from the ducts is impaired (Dodd and Booth 2000). Heuven et al., (1988) showed also that where SCC was considered as a concentration of cells (i.e., cells per milliitre), the correlation between SCC and milk production was negative, supporting the current results, and the dilution effect theory. They also found that the phenotypic correlation between milk production and SCC (as the total number of cells shed) was positive. This indicates that more cells are shed, with increasing milk production. Whether the increase in cells shed with increasing milk yield was indicative of an increased mastitis incidence or due to a higher rate of turnover of cells within glands, producing greater quantities of milk is uncertain. Pryce et al. (1998) also reported a negative phenotypic correlation between milk production and SCC.

\section{Association between MU and milk production traits}

Least squares means and standard errors of MU by TDM categories are given in Table 7 and Figure 4b and by PP categories are given in Table 8 and Figure $5 \mathrm{~b}$. On contrast, least squares means and standard errors of TDM, PP and PY by MU categories are given in Table 9 and Figures $6 a$ and b. From these tables, it could be noticed that there are positive relationships between MU and milk production traits. The lowest TDM category $(\leq 15 \mathrm{~kg})$ had the lowest MU $(26.9 \mathrm{Mg} / \mathrm{dl})$, meanwhile the highest TDM category (>30 $\mathrm{kg})$ had the highest MU $(38.9 \mathrm{Mg} / \mathrm{dl})($ Table 7$)$. The lowest PP category (< $3.0 \%)$ had the lowest MU $(30.8 \mathrm{Mg} / \mathrm{dl})$, meanwhile the PP category between 3.6 to $3.8 \%$ had the highest $\mathrm{MU}(33.4 \mathrm{Mg} / \mathrm{dl})$ (Table 8). The lowest MU category $(<15 \mathrm{Mg} / \mathrm{dl})$ had the lowest TDM $(16.7 \mathrm{~kg})$ and PP $(3.38 \%)$, 
meanwhile the highest MU category (> $55 \mathrm{Mg} / \mathrm{dl}$ ) had the highest TDM (28.6 $\mathrm{kg}$ ) and PP (3.46\%) (Table 9). The positive relationships between MU and milk traits were found also by several authors (Oltner et al., 1985; Gustafsson and Palmquist, 1993; Butler et al., 1995; Carlsson et al., 1995 and Hojman et al., 2004\&2005), whereas others have found a negative relationship (Ismail et al., 1996; Broderick and Clayton 1997 and Johnson and Young 2003) or no association between them (Baker et al., 1995; Godden et al., 2001 and Rajala-Schultz and Saville 2003). Eicher et al. (1999) found the associations between MUN or milk protein percentage with respect to production factors such as DIM, parity and milk production, considerably varied among dairy herds. Godden et al. (2000a) found a positive nonlinear association between cow-level MUN and milk yield and a negative nonlinear association between MUN and milk fat and protein percentage and a significant negative nonlinear association with somatic cell linear score. Johnson and Young (2003) found that MUN was inversely associated with milk protein percentage and paralleled change in milk yield over time.

The conflicting findings among various studies regarding the relationship between $\mathrm{MU}$ and milk yield might have several explanations. An explanation for a positive relationship between $\mathrm{MU}$ and production is that higher protein feeding, associated with higher MU concentrations, also supports higher milk production (Oldham 1984). This may be due to a combination of factors including greater amino acid availability for milk protein synthesis, improved availability of energy through deamination of amino acids, improved efficiency of utilization of absorbed nutrients, or improved dry matter intake (Macleod et al., 1984; Oldham 1984). Conversely, an explanation for a negative relationship between $\mathrm{MU}$ and production is that the energy tax associated with the conversion of excess amounts of ammonia to urea may contribute to lower available energy for milk production (Nelson 1996). The conversion of ammonia to urea in the liver has been estimated to cost the animal $12 \mathrm{Kcal} / \mathrm{g}$ of excess nitrogen excreted (Van Soest 1994). Vandehaar (1998) predicted that if a cow producing $45 \mathrm{~kg}$ of milk/d and eating $25 \mathrm{~kg}$ of dry matter/day required $17 \%$ crude protein (CP) in its diet, then feeding an extra two percentage points of protein (a diet of $19 \% \mathrm{CP}$ ) would amount to an energy expense of $0.36 \mathrm{Mcal} / \mathrm{day}$. Other factors influencing the relationship between $\mathrm{MU}$ and production could include the type and quality of dietary protein provided, including amino acid availability. While MU concentration may be sensitive to levels of crude protein, rumen degradable protein and rumen undegradable protein, it has been reported not to be associated with amino acid balance (Baker et al., 1995). Additionally, although high $\mathrm{MU}$ concentrations will indicate the relatively high protein:energy ratio, they do not necessarily indicate which of these two nutrients is in relative excess or deficiency (Oltner and Wiktorsson 1983). The latter study observed that $\mathrm{MU}$ concentrations remained moderate so long as levels of protein and energy were balanced relative to one another, whether or not they were both fed in excess, both underfed, or both fed at recommended levels (Oltner and Wiktorsson 1983). Clearly, variations in any or all of these nutrient composition variables could result in different levels of 
Oudah, E. Z. M.

production among different studies, leading to contradictory findings as to the nature of the relationship between MU and production.

\section{Association between SCC and MU}

Least squares means and standard errors of MU by SCS categories are given in Table 6 and Figure 3a. On contrast, least squares means and standard errors of SCC measures by MU categories are given in Table 9 and Figure $6 \mathrm{a}$. From these tables, it could be noticed that there are negative relationships between $\mathrm{MU}$ and SCC measures. SCC followed MU concentrations in an inverse order. Milk urea content, adjusted for the other factors, significantly decreases with increasing SCS. The first SCS category $(0-3)$ had the highest MU (33.2 mg/dl) whereas; the last SCS category (7-9) had the lowest MU $(30.6 \mathrm{mg} / \mathrm{dl})$. On the other hand, SCC and SCS were $546,000 \mathrm{cell} / \mathrm{ml}$ and 4.10 , respectively in test-day samples contain $<15 \mathrm{mg} / \mathrm{dl}$ $\mathrm{MU}$, meanwhile they were $307,000 \mathrm{cell} / \mathrm{ml}$ and 3.38, respectively in test-day samples contain $>55 \mathrm{mg} / \mathrm{dl}$ MU. Average SCC for MU 1-6 categories were $546,445,420,348,333$ and 307 cell $(\times 1000) / \mathrm{ml}$, respectively (Table 9$)$. Little research has been published exploring the association between $\mathrm{MU}$ and SCC. Godden et al. (2001), Rajala-Schultz and Saville (2003) and Hojman et al. (2004 and 2005) found that the relationship of MU with SCC was strongly negative. Hojman et al. (2004) considered the relationship between $\mathrm{Mu}$ and SCC as a puzzle, that those variables refer to physiological processes that are not clearly connected. Milk urea is related to protein and NPN supply and their utilization rate in the rumen; SCC reflects the degree of irritation in the udder. Godden et al. (2001b) reported a negative association between cowlevel MUN and linear score in 60 commercial Ontario Holstein herds over a 13-mo period, but no association between herd average linear score and herd average MUN. Stoop et al. (2007) found a strong genetic correlation of milk urea with SCS (0.85). They added that the genetic correlation was surprising because the phenotypic correlation was weak $(0.00)$. The phenotypic correlation was in line with other studies. $\mathrm{Ng}$-Kwai-Hang et al. (1985) demonstrated a slight increase in non-protein nitrogen with increasing SCC. They reported a small but significant positive association between SCC and milk NPN levels (which includes urea). Meanwhile, Eicher et al. (1999) found insignificant effect of SCC on urea. Godden et al. (2001) found significant negative nonlinear association between cow-level MU and linear score of SCC. Stoop et al. (2007) stated that the high genetic correlation of milk urea with SCS (0.85), suggests that the same genetic mechanism is associated with SCS and MUN, e.g., possibly due to changes in protein metabolism during episodes of mastitis. DePeters and Ferguson (1992), in a review of previous studies, reported that milk from mastitic glands was lower in casein and higher in noncasein protein. They suggested that casein breakdown products contributed to the whey protein fraction of mastitic milk. Rajala-Schultz and Saville (2003) found that milk SCC (expressed as linear score) was negatively associated with MUN in the high production herds $(\mathrm{P}<$ 0.01 ) but no association in the low producing herds. They added that with a unit increase in linear score, MUN concentration decreased by $0.2 \mathrm{mg} / \mathrm{dl}$. Faust et al. (1997) reported that MUN values were lowest for samples with largest SCC. These observations would agree with our finding that increasing 
SCC was associated with decreasing MUN. Arunvipas et al. (2003) found that linear score had a strong negative relationship with MUN concentration. Godden et al. (2000) made the comment that it is unknown how much of the negative association observed between MUN and somatic cells is attributable to the failure of the computer algorithm to control completely for the negative interfering effect of somatic cells when measuring urea in samples with veryhigh SCC. 
Oudah, E. Z. M.

$8+9$ 
J. Agric. Sci. Mansoura Univ., 34 (9), September, 2009

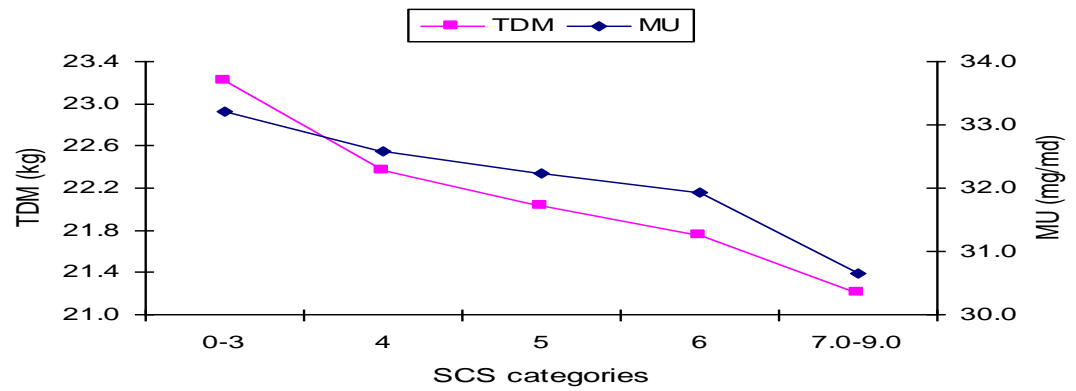

Figure 3a: TDM and MU by SCS categories

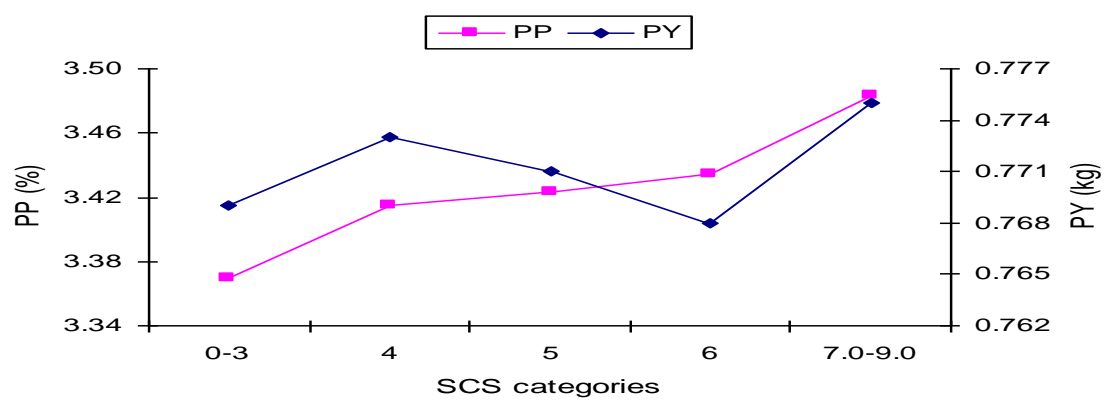

Figure 3b: PP and PY by SCS categories

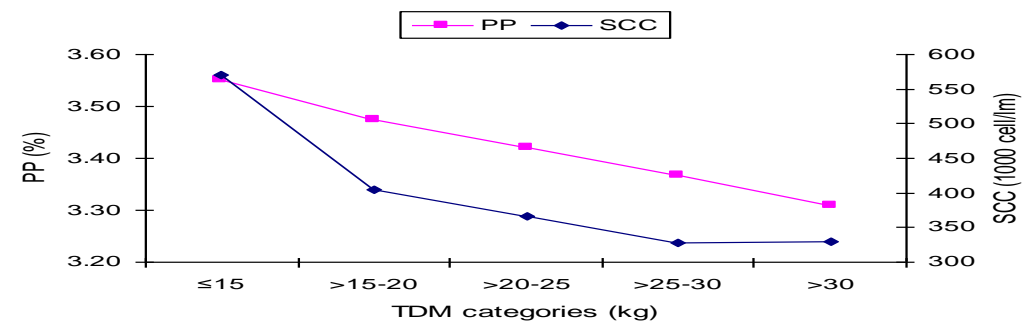

Figure 4a: SCC and PP TDM categories

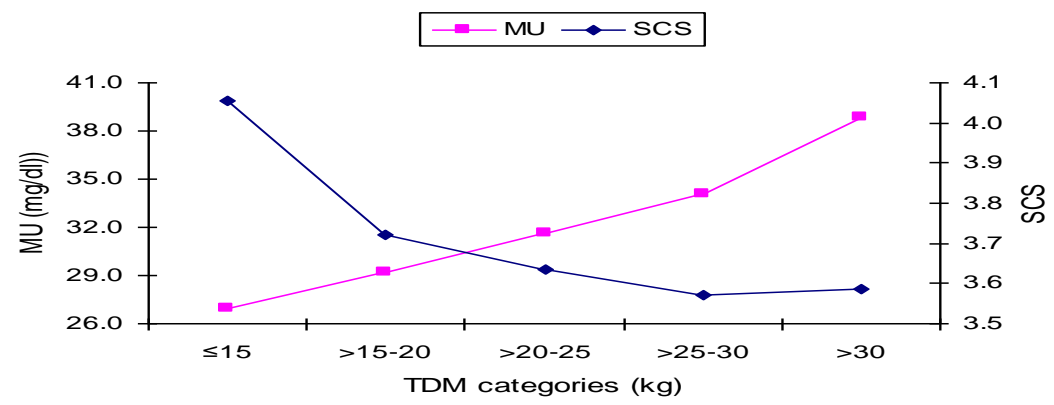

Figure 4b: MU and SCS by TDM categories 
Oudah, E. Z. M.

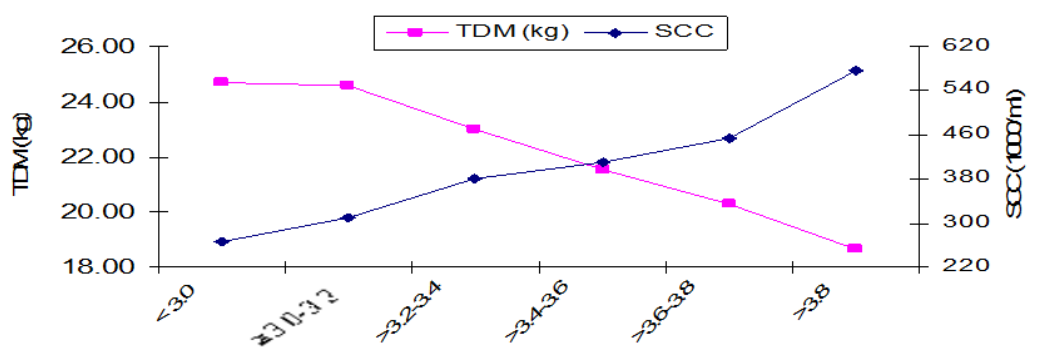

PP categories (\%)

Figure 5a: TDM and SCC by PP categories

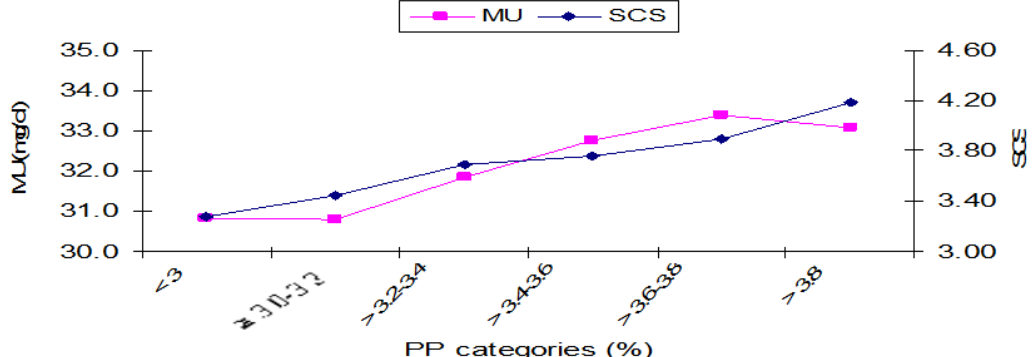

Figure 5b: MU and SCS by PP categories

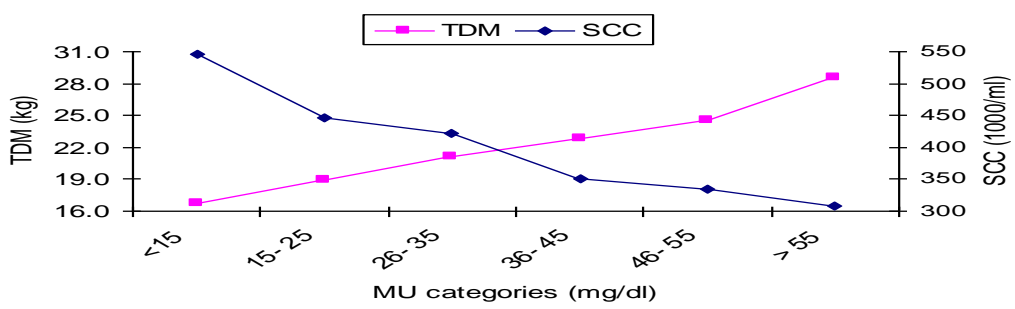

Figure 6b: TDM and SCC by MU categories

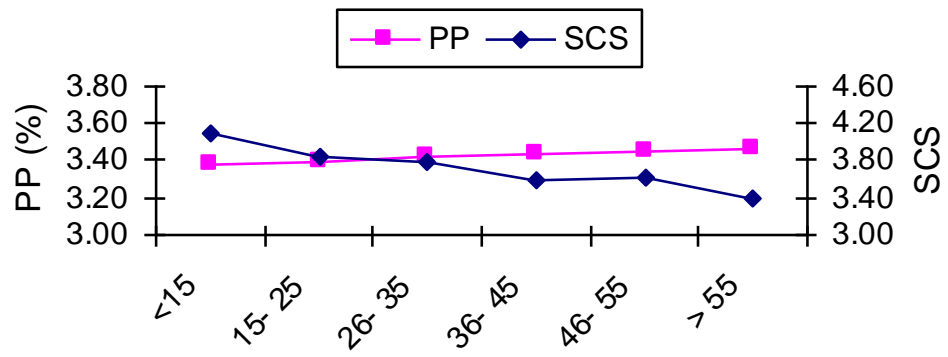

$\mathrm{MU}$ categories $(\mathrm{mg} / \mathrm{dl})$

Figure 6a: PP and SCS by MU categories 


\section{Association between milk production traits}

Least squares means and standard errors of PP and PY by TDM categories are given in Table 7 and Figure 4a. On contrast, least squares means and standard errors of TDM by PP categories are given in Table 8 and Figure 5a. A negative linear relationship between milk yield and PP in the same milking was observed. TDM for PP less than $3.2 \%$ was $24.6 \mathrm{~kg}$, meanwhile, it was $18.6 \mathrm{~kg}$ for PP $>3.8$. >From these Tables, it could be noticed that there is a significant negative relationship between PP and TDM.

\section{Conclusion}

- Highly significant effects $(P<0.001)$ on SCC, MU and milk production traits were found for MOR and DIM. Therefore, the effects of environmental variables must be taken into consideration when cows are evaluated and when developing and comparing models to be used in adjusting data to provide the best estimates of genetic parameters for selection purposes in the dairy cattle evaluation.

- The results demonstrate the importance of surroundings and management practice. Therefore, management play a great role as source of variability and has a effective role in maintaining optimum SCC and MU levels for health status and nutrition.

- Milk urea content varied by different environmental variables, so researchers should consider controlling for these variables as potential confounders when exploring the relationship between $\mathrm{MU}$ and nutritional management or measures of performance such as production or reproduction.

- The results suggest that MU should be evaluated in association with month of the year, DIM, milk yield, and protein percentage when determining the efficiency of $\mathrm{N}$ utilization.

\section{Acknowledgements}

The author wishes to thank Pavel Bucek from the Czech Moravian Breeders' Corporation, Inc., Hiradistko, Czech Republic for providing the data. Thanks also are extended to European Commission, DirectorateGeneral for Education and Culture (Tempus Project) for financial support through the individual mobility grant (IMG) to Institute of Animal Science, Prague-Uhrinives, Prague, The Czech Republic (IMG_EG3044-2004). The author gratefully acknowledges Dr. Jarmila Bohmanova, Department of Animal and Poultry Science, University of Guelph, ON, Canada for revising the manuscript.

\section{REFERENCES}

Arunvipas, P.; Dohoo, I.R.; Van Leeuwen, J.A. and Keefe, G. P. (2003). The effect of non-nutritional factors on milk urea nitrogen levels in dairy cows in Prince Edward Island, Canada. Preventive Veterinary Medicine 59: 83-93.

Arunvipas, P., Van Leeuwen, J. A.; Dohoo, I. R. and Keefe, G. P. (2004). Bulk tank milk urea nitrogen: Seasonal patterns and relationship to individual cow milk urea nitrogen values. The Canadian Journal of Veterinary Research, 68: 169-174. 
Atakan, K. O. Ç. (2008). A Study of somatic cell counts in the milk of HolsteinFriesian cows managed in Mediterranean climatic conditions. Turkish Journal Veterinary Animal Science, 32(1): 13-18.

Auldist, M. J.; Coats, S.; Rogers, G. L. and McDowell, G. H. (1995). Changes in the composition of milk from healthy and mastitic dairy cows during the lactation cycle. Australian Journal of Experimental Agriculture, 35: 427436.

Auldist, M. J. and Hubble, I. B. (1998). Effects of mastitis on raw milk and dairy products. The Australian Journal of Dairy Technology, 53: 28-36.

Baker, L. D., Ferguson, J. D. and Chalupa, W. (1995). Reponses in urea and true protein to different feeding schemes for dairy cows. J. Dairy Sci., 78: 2424-2434.

Barker, A. R.; Schrick, F. N.; Lewis M. J.; Dowlen, H. H.; Oliver, S. P. (1998). Influence of clinical mastitis during early lactation on reproductive performance of Jersey cows. J. Dairy Sci., 81: 1285-1290.

Bodoh, G. W.; Banista, W. J.; Schultz, L. H. and Johnson Jr. R. P. (1976). Variation in somatic cell counts in Dairy Herd Improvement milk samples. J. Dairy Sci., 59: 1119-1123.

Broderick, G. A. and Clayton, M. K. (1997). A statistical evaluation of animal and nutritional factors influencing concentrations of milk urea nitrogen. J. Dairy Sci., 80: 2964-2970.

Bruckental, J.; Oldham, D. and Sutton, J. D. (1980). Glucose and urea kinetics in cows in early lactation. British Journal of Nutrition, 44: 33-45.

Butler, W. R.; Calaman, J. J. and Beam, S. W. (1995). Plasma and milk urea nitrogen in relation to pregnancy rate in lactating dairy cattle. J. Anim. Sci., 74: 858-865.

Calberry, J. (2003). Milk urea nitrogen testing to improve protein utilization in dairy cattle. Factsheet, Ontario Ministry of Agriculture Food and Rural Affairs. $\quad$ http://www.omafra.gov.on.ca/english/livestock/dairy/facts/03117.htm

Calus, M. P. L.; Janss, L. L. G. and Veerkamp, R. F. (2006). Genotype by environment interaction for somatic cell score across bulk milk somatic cell count and days in milk. J. Dairy Sci., 89: 4846-4857.

Capuco, A. V. and Akers, R. M. (1999). Mammary involution in dairy animals. Journal of Mammary Gland Biology, Neoplasia, 4: 137-144.

Carlén, E.; Strandberg, E. and Roth, A. (2004). Genetic parameters for clinical mastitis, somatic cell score and production in the first three lactations of Swedish Holstein cows. J. Dairy Sci., 87: 3062-3070.

Carlsson, J. J.; Bergstro, M. and Pehrson, B. (1995). Variations with breed, age, season, yield, stage of lactation and herd in the concentration of urea in bulk milk and individual cow's milk. Acta Veterinaria Scandinavia 36: 245-254.

Coffey, E.; Vinson, E. and Pearson, E. (1986). Potential of somatic cell concentration in milk as a sire selection criterion to reduce mastitis in dairy cattle. J. Dairy Sci., 69: 2163-2172.

Coulon, J. B.; Dauver, F.; Garel, J. P. (1996). Facteurs de variation de la umration cellulaire du lait chez des vaches laiti res indemnes de mammites cliniques (Changes in somatic cell count in dairy cows free of clinical mastitis). INRA Prod. Anim. 9 (2): 133-139. http://granit.jouy.inra.fr/productionsanimales/1996/Prod Anim 1996 92 05.pdf

De Haas, Y.; Ouweltjes, W.; Napel, J. ten.; Windig, J. J. and De Jong, G. (2008). Alternative Somatic Cell Count Traits as Mastitis Indicators for Genetic Selection. J. Dairy Sci., 91: 2501-2511. 
De Peters, E. J. and Ferguson, J. D. (1992). Nonprotein nitrogen and protein distribution in the milk of cows. J. Dairy Sci., 75: 3192-3209.

Dodd, F. H. and Booth, J. M. (2000). Mastitis and milk production. In: Andrews A. H. (Editor), The Health of Dairy Cattle. Blackwell Science Ltd., Oxford, UK, pp. 213-255.

Dohoo, I. R. (1993). An evaluation of the validity of individual cow somatic cell counts from cows in early lactation. Preventive Veterinary Medicine 16: 103-110.

Dürr, J. W.; Cue, R. I.; Monardes, H. G.; Moro-Méndez, J. and Wade, K. M. (2008). Milk losses associated with somatic cell counts per breed, parity and stage of lactation in Canadian dairy cattle. Livestock Science, 117: 225-232.

Eicher, R.; Bouchard, E. and Bigras-Poulin, M. (1999). Factors affecting milk urea nitrogen and protein concentrations in Quebec dairy cows. Preventive Veterinary Medicine 39: 53-63.

Emanuelson, U.; Danell, B. and Philipsson, J. (1988). Genetic parameters for clinical mastitis, somatic cell counts and milk production estimated by multiple-trait restricted maximum likelihood. J. Dairy Sci., 71: 467-476.

Emanuelson, U. and Persson, E. (1984). Studies on somatic cell counts in milk from Swedish dairy cows. I. Nongenetic causes of variation in monthly test-day results. Acta Agriculture Scandinavia, 34: 33-44.

Faust, M. A.; Kilmer, L. H. and Funk, R. (1997). Effects of laboratories for milk urea nitrogen and other milk components. J. Dairy Sci., 80 (Supplement 1): 249. (Abstract).

Ferguson, J. D. (2002). Milk Urea Nitrogen. Center for Animal Health and Productivity. Pennsylvania University http://cahpwww.vet.upenn.edu/mun/mun info.html

Ferguson, J. D.; Thomsen, N.; Slesser, D. and Burris, D. (1997). Pennsylvania DHIA milk urea testing. J. Dairy Sci., 80 (Supplement 1):161 (Abstract).

Fetrow, J.; Mann, D.; Butcher, K. and McDaniel, B. (1991). Production losses from mastitis: Carry-over from the previous lactation. J. Dairy Sci., 74: 833-839.

Garcia, A. D.; Linn, J. G.; Stewart, S. C.; Olson, J. D. and Olson, W. G. (1997). Evaluation of milk urea nitrogen (MUN) as a dietary monitor for dairy cows. J. Dairy Sci., 80(Supplement 1): 161 (Abstract)

Godden, S. M.; Lissemore, K. D.; Kelton, D. F.; Leslie, K. E.; Walton, J. S. and Lumsden, J. H. (2000). Factors associated with milk urea concentrations in Ontario dairy cows. J. Dairy Sci., 83: 2672-2672.

Godden, S.M.; Lissemore, K.D.; Kelton, D. F.; Lumsden, J. H.; Leslie, K. E. and Walton, J. S. (2000a). Analytic validation of an infrared milk urea assay and effects of sample acquisition factors on milk urea results. J. Dairy Sci., 83: 435-442.

Godden, S. M.; Kelton, D. F.; Lissemore, K. D.; Walton, J. S.; Leslie, K. E. and Lumsden, J. H. (2001). Milk urea testing as a tool to monitor reproductive performance in Ontario dairy herds. J. Dairy Sci., 84:1397-1406.

Godden, S. M.; Lissemore, K. D.; Kelton, D. F.; Leslie, K. E.; Walton, J. S. and Lumsden, J. H. (2001a). Factors associated with milk urea concentrations in Ontario dairy cows. J. Dairy Sci., 84:107-114.

Godden, S. M.; Lissemore, K. D.; Kelton, D. F.; Leslie, K. E.; Walton, J. S. and Lumsden, J. H. (2001b). Relationships between milk urea concentration and nutritional management, production and economic variables in Ontario dairy herd. J. Dairy Sci., 84: 1128-1139.

Gustafsson, A. H. and Palmquist, D. L. (1993). Diurnal variation of rumen ammonia, serum urea and milk urea in dairy cows at high and low yields. J. Dairy Sci., 76: 475-484. 
Haile-Mariam, M.; Goddard, M. E. and Bowman, P. J. (2001). Estimates of Genetic Parameters for Daily Somatic Cell Count of Australian Dairy Cattle. J. Dairy Sci., 84: 1255-1264.

Heuven, H. C. M.; Bovenhuis, H. and Politiek, R. D. (1988). Inheritance of somatic cell count and its genetic relationship with milk yield in different parities. Livestock Production Science, 18: 115-127.

Hojman, D., Gips, M. and Ezra, E. (2005). Association between live body weight and milk urea concentration in Holstein cows. J. Dairy Sci., 88: 580-584.

Hojman, D.; Kroll, O.; Adin, G.. Gips, M.; Tavori, B, and Ezra, E. (2004). Relationships between milk urea and production, nutrition and fertility traits in Israeli dairy herds. J. Dairy Sci., 87: 1001-1011.

Ikonen, T.; Morri, S.; Tyrisevä, A.M.; Ruottinen, O. and Ojala, M. (2004). Genetic and phenotypic correlations between milk coagulation properties, milk production traits, somatic cell count, casein content and pH of milk. J. Dairy Sci., 87: 458-467.

Johnson, R. G. and Young. A. J. (2003). The association between milk urea nitrogen and $\mathrm{DHI}$ production variables in western commercial dairy herds. J. Dairy Sci., 86: 3008-3015.

Jonker, J. S.; Kohn, R. A. and High, J. (2002) Use of milk urea nitrogen to improve dairy cow diets. J. Dairy Sci., 85:939-946.

Jones, G. M.; Pearson, R. E.; Clabaugh, G. A. and Heald, C. W. (1984). Relationships between somatic cell counts and milk production. J. Dairy Sci., 67:1823-1831.

Kennedy, B. W.; Sethar, M. S.; Tong, A. R.; Moxley, J. E. and Downey, B. R. (1982). Environmental factors influencing test day somatic cell counts in Holsteins. J. Dairy Sci., 65: 275-280.

Kiiman, H. and Kaart, T. (2004). On somatic cell count in milk. In: Proceedings of the $10^{\text {th }}$ Animal Breeding in Baltic's Conference. 13-14 May, Institute of Animal Science, Estonian Agricultural University, Tartu, Estonia, 2004. PP: 36-39 http://www.eau.ee/ /ki/babc/X/

Kohn, R. A.; Dinneen, M. M. and Russek-Cohen, E. (2005). Using blood urea nitrogen to predict nitrogen excretion and efficiency of nitrogen utilization in cattle, sheep, goats, horses, pigs and rats, J. Anim. Sci., 83: 879-889.

Kohn, R. A.; Kalscheur, K. F. and Russek-Cohen, E. (2002). Evaluation of Models to Estimate Urinary Nitrogen and Expected Milk Urea Nitrogen. J. Dairy Sci., 85: 227-233.

Koivula, M.; Mantyssaari, E. A.; Negussie, E. and Serenius, T. (2005). Genetic and phenotypic relationships among milk yield and somatic cell count before and after clinical mastitis. J. Dairy Sci., 88: 827-833.

Kureoja, A. and Kaart, T. (2004). Genetic and environmental influences on urea concentration in dairy cows, milk. In: Proceedings of the $10^{\text {th }}$ Animal Breeding in Baltic's Conference. 13-14 May, Institute of Animal Science, Estonian Agricultural University, Tartu, Estonia, 2004. PP: 42-47 http://www.eau.ee/ /ki/babc/X/

Macleod, G. K.; Grieve, D. G.; McMillan, I. and Smith, G. C. (1984). Effect of varying protein and energy densities in complete rations. J. Dairy Sci., 67: $1421-1429$.

Miglior, F.; Sewalem, A.; Jamrozik, J.; Lefebvre, D. M. and Moore, R. K. (2006). Analysis of milk urea nitrogen and lactose and their effect on longevity in Canadian dairy cattle. J. Dairy Sci., 89: 4886-4894.

Miller, R. H.; Emanuelson, U.; Persson, E.; Brolund, L.; Philipsson, J. and Funke, H. (1983). Relationships of milk somatic cell counts to daily milk yield and composition. Acta Agriculture Scandinavia 33: 209-223. 
Miller, R. H.; Norman, H. D.; Wiggans, G. R. and Wright, J. R. (2004). Relationship of test day somatic cell score with test day and lactation milk yields. J. Dairy Sci., 87: 2299-2306.

Moller, S.; Matthew, C. and Wilson, G. F. (1993). Pasture protein and soluble carbohydrate levels in spring dairy pasture and associations with cow performance. Proceedings of the New Zealand Society of Animal Production 54: 83-86.

Mostert, B. E.; Banga, C.; Groeneveld, E. and Kanfer, F. H. J. (2004). Breeding value estimation for somatic cell score in South African dairy cattle. South African J. Anim. Sci., 34 (Supplement 2): 32-34.

Nelson, A. J. (1996). Practical application of MUN analysis. The AABP Bovine Proceedings 29: 85-95.

Ng-Kwai-Hang, K. F.; Hayes, J. F.; Moxely, J. E. and Monardes, H. G. (1985). Percentages of protein and nonprotein nitrogen with varying fat and somatic cells in bovine milk. J. Dairy Sci., 68:1257-1262.

Norman, H. D.; Miller, R. H.; Wright, R. and Wiggans, G. R. (2000). Herd and state means for somatic cell count from dairy herd improvement. J. Dairy Sci., 83: 2782-2788.

Oldham, J. D. (1984). Protein-energy interrelationships in dairy cows. J. Dairy Sci., 67:1090-1114

Oltner, R.; Emanuelson, M. and Wiktorsson, H. (1985). Urea concentration in cow's milk in relation to milk yield, live weight, lactation number and composition of feed given. Livestock Production Science, 12: 45-57.

Oltner, R. and Wiktorsson, H. (1983). Urea concentrations in milk and blood as influenced by feeding varying amounts of protein and energy to dairy cows. Livestock Production Science, 10: 457-467.

Oudah, E.Z.M. (2009). Phenotypic relationships among somatic cell count, milk urea content, test-day milk yield and protein percent in dairy cattle. J. Agric., Sci., Mansoura Univ., 34(9): 9377 - 9383.

Philipsson, J., Ral, G. and Berglund, B. (1995). Somatic cell count as a selection criterion for mastitis resistance in dairy cattle. Livestock Production Sci. 41: 195-200.

Pryce, J. E.; Esslemont, R, J.; Thompson, R.; Veerkamp, R. F.; Kossaibati, M. A. and Simm, G. (1998). Estimation of genetic parameters using health, fertility and production data from a management recording system for dairy cattle. Animal Science, 66: 577-584.

Rajala-Schultz, P. J. and Saville, W. J. A. (2003). Sources of Variation in Milk Urea Nitrogen in Ohio Dairy Herds. J. Dairy Sci., 86: 1653-1661.

Raubertas, R. F. and Shook, G. E. (1982). Relationship between lactation measures of somatic cell concentration and milk yield. J. Dairy Sci., 65: 419-425.

Reents, R.; Jamrozik, J.; Schaeffer, L. R. and Dekkers, J.C.M. (1995). Estimation of genetic parameters for test day records of somatic cell score. J. Dairy Sci., 78: 2847-2857.

Rekik, B.; Ajili, N.; Belhani, H.; Ben Gara, A. and Rouissi, H. (2008). Effect of somatic cell count on milk and protein yields and female fertility in Tunisian Holstein dairy cows. Livestock Production Science, 116: 309317.

Rodriguez-Zas, Sandra L.; Gianola, D. and Shook, G. E. (2000). Evaluation of models for somatic cell score lactation patterns in Holsteins. Livestock Production Science, 67: 19-30. 
Ruegg, P. L.; Pantoja, J. and Hulland, C. (2008). Intramammary Infections and Somatic Cell Counts across the Dry Period. XII Curso Novos Enfoques $\mathrm{Na}$ Producaoe reproducao de Bovinos, Uberlandia Brazil, March 6-8, 2008 http://www.uwex.edu/milkquality/PDF/Ruegg\%20IMI\%20and\%20SCC\% 20dry\%20period\%20Brazil\%202008.pdf

Sargeant, J. M.; Schukken, Y. H. and Leslie, K. E. (1998). Ontario bulk milk somatic cell count reduction program: progress and outlook. J. Dairy Sci., Vol. 81. p. 1545-1554.

SAS (2004). SAS Institute, Inc. 2004. User's guide. Version 9.0. SAS Institute, Inc., Cary, NC, USA.

Schaeffer, L. R.; Jamrozik, J.; Kistemaker, G. J. and Van Doormaal, B. J. (2000). Experience with a Test - Day Model. J. Dairy Sci., 83: 11351144.

Schepers, A. J. and Meijer, R. G. M. (1998). Evaluation of the Utilization of Dietary Nitrogen by Dairy Cows Based on Urea Concentration in Milk. J. Dairy Sci., 81: 579-584.

Sheldrake, R. F.; McGregor, G. D. and Hoare. R.J.T. (1983). Somatic Cell Count, Electrical Conductivity and Serum Albumin Concentration for Detecting Bovine Mastitis. J. Dairy Sci., 66: 548-555.

Shook, G. E. (1982). A linear scale for scoring somatic cell count. J. Dairy Sci., 65: supplement I): 108 (Abstract).

Shuster, D. E.; Harmon, R. J.; Jackson, J. A. and Hemken, R. W. (1991). Suppression of milk production during endotoxin-induced mastitis. J. Dairy Sci., 74(11): 3763-3774.

Stoop, W. M.; Bovenhuis, H. and Arendonk, J. A. M. van (2007) Genetic Parameters for Milk Urea Nitrogen in Relation to Milk Production Traits. J. Dairy Sci., 90: 1981-1986.

Spicer, L. J.; Francisco, C.C.; Jones, D. and Waldner, D. N. (2000). Changes in milk urea nitrogen during early lactation in Holstein cows. Animal Science Research Report Pages, Oklahoma Agricultural Experiment Station, Oklahoma State University, pp. 169-171.

Vandehaar, M. J. (1998). Efficiency of nutrient use and relationship to profitability on dairy farms. J. Dairy Sci., 81:272-282.

Van Schaik, G.; Lotem, M. and Schukken, Y. H. (2002). Trends in somatic cell Counts, bacterial counts and antibiotic residue violations in New York State during 1999-2000. J. Dairy Sci., 85: 782-789.

Van Soest, P. J. (1994). Nutritional Ecology of the Ruminant. Cornell University Press. Ithaca, New York.

Wattiaux, M. A.; Nordheim, E. V. and Crump, P. (2005). Statistical Evaluation of Factors and Interactions Affecting Dairy Herd Improvement Milk Urea Nitrogen in Commercial Midwest Dairy Herds. J. Dairy Sci., 88: 30203035 .

Weller, J.; Sran, A. and Zelige, Y. (1992). Genetic and environmental relationships among somatic cell count, bacterial infection and clinical mastitis. J. Dairy Sci., 75: 2532-2540.

Wicks, H. C. F. and Leaver, J. D. (2006). Influence of genetic merit and environment on somatic cell counts of Holstein-Friesian cows. The Veterinary Journal, 172: 52-57.

Wiggans, G. R. (1986). Projection of protein yield to 305 days. J. Dairy Sci., 69: 2908-2914.

Wiggans, G. R. and Shook, G. E. (1987). A lactation measure of somatic cell count. J. Dairy Sci., 70: 2666-2672. 
Wood, P. D. P. (1976). Algebraic models of the lactation curve for milk, fat and protein production with estimates of seasonal variation. Animal Production 22: 35-40.

Wood, G. M.; Boettcher, P. J.; Jamrozik, J.; Jansen, G. B. and Kelton, D. F. (2003). Estimation of Genetic Parameters for Concentrations of Milk Urea Nitrogen. J. Dairy Sci., 86: 2462-2469.

$$
\begin{aligned}
& \text { العوامل غير وراثية المؤئرة على عدد الخلايـا الجسدية بـاللبن، محتوى اللبن من فن فئن }
\end{aligned}
$$

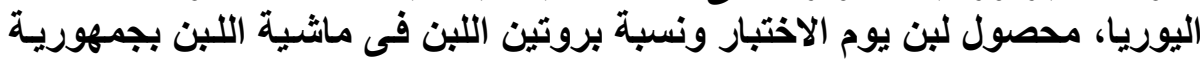

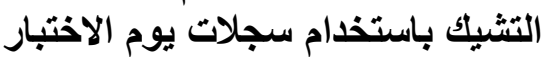

$$
\begin{aligned}
& \text { السعيد زهرى محمد عودة لانجات }
\end{aligned}
$$

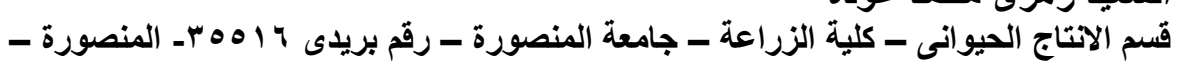

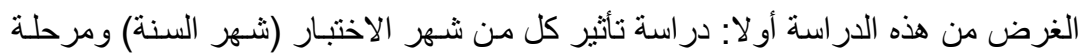

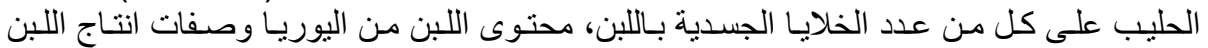

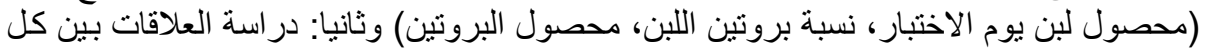

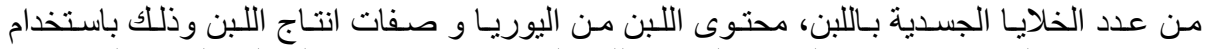

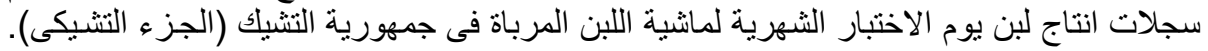

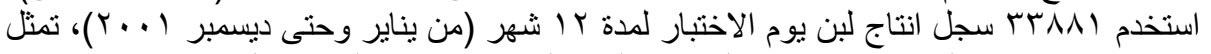

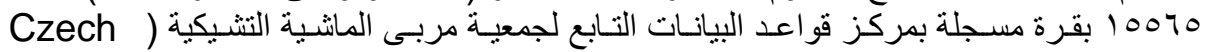
Moravian Breeders' Corporation, Inc.

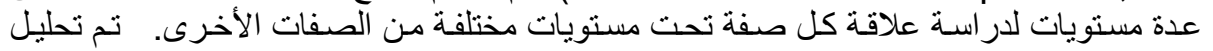

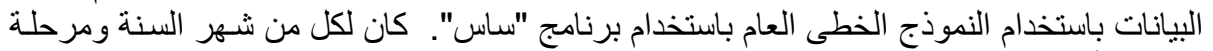

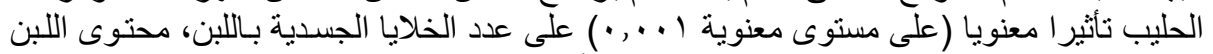

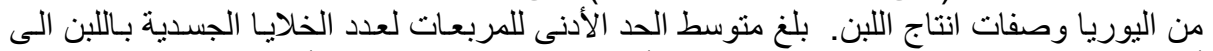

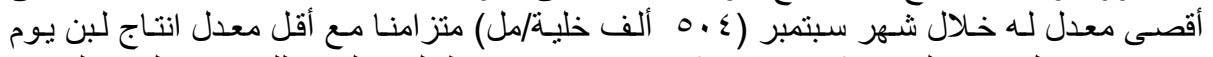

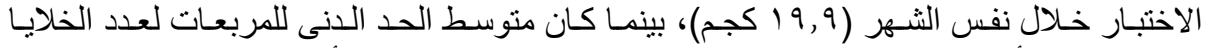

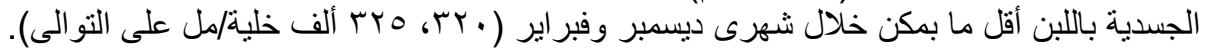

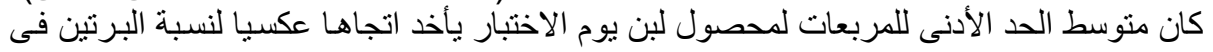

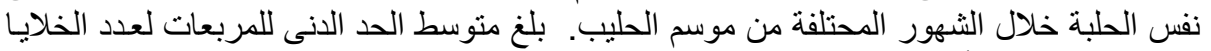

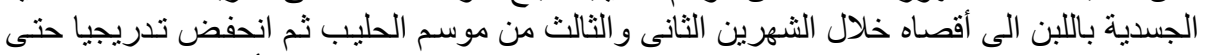

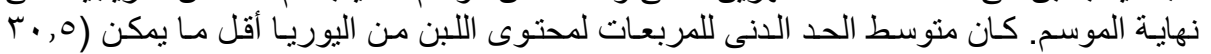

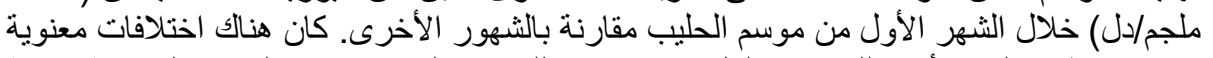

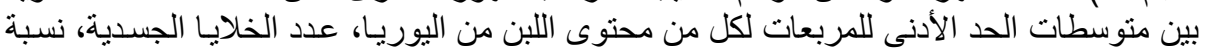

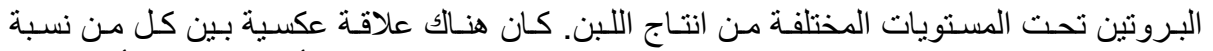

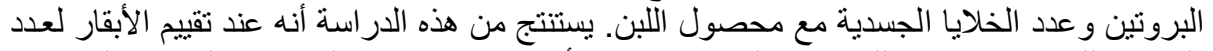

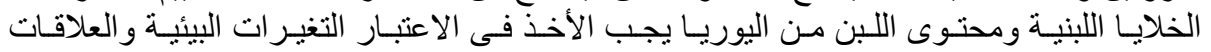
المظهرية بين الصفات وبعضها البعض. 
Oudah, E. Z. M.

Table 4: Least squares means (LSM) and standard errors (SE) of somatic cell count (SCC, $1000 \mathrm{cell} / \mathrm{ml}$ ), somatic cell score (SCS), test-day, Milk yield (TDM, kg), milk urea content (MU, mg/dl), protein percentage (PP\%) and protein yield (PY, $\mathrm{kg}$ ) by month of recording (MOR)*

\begin{tabular}{|c|c|c|c|c|c|c|c|c|c|c|c|c|c|c|}
\hline \multirow{3}{*}{ MOR } & \multicolumn{2}{|c|}{ Observations } & \multicolumn{12}{|c|}{ Trait } \\
\hline & \multirow{2}{*}{ No. } & \multirow{2}{*}{$\%$} & \multicolumn{2}{|c|}{ SCC } & \multicolumn{2}{|c|}{ SCS } & \multicolumn{2}{|l|}{ MU } & \multicolumn{2}{|c|}{ TDM } & \multicolumn{2}{|c|}{ PP } & \multicolumn{2}{|c|}{ PY } \\
\hline & & & LSM & SE & LSM & SE & LSM & SE & LSM & SE & LSM & SE & LSM & SE \\
\hline January & 2762 & 8.66 & $365 a$ & 19.4 & $3.75 a$ & 0.046 & 34.1adf & 0.26 & $20.7 a$ & 0.18 & $3.45 a b$ & 0.008 & $0.766 a$ & 0.003 \\
\hline February & 3324 & 10.43 & $335 a$ & 17.3 & $3.57 a$ & 0.041 & $29.1 \mathrm{e}$ & 0.24 & $22.9 b d$ & 0.16 & $3.46 a$ & 0.007 & $0.785 b$ & 0.002 \\
\hline March & 2593 & 8.13 & $398 a$ & 18.4 & $3.74 a$ & 0.044 & 25.2 & 0.25 & $22.9 b c$ & 0.17 & $3.43 b c$ & 0.008 & $0.774 a$ & 0.003 \\
\hline April & 2406 & 7.55 & $384 a$ & 20.5 & $3.58 a$ & 0.049 & 31.3 & 0.28 & $22.3 \mathrm{~cd}$ & 0.19 & 3.37 & 0.009 & $0.761 a$ & 0.003 \\
\hline May & 2650 & 8.31 & $393 a$ & 17.3 & $3.73 a$ & 0.041 & $36.1 \mathrm{a}$ & 0.24 & $22.1 e$ & 0.16 & $3.45 \mathrm{ad}$ & 0.007 & $0.773 a$ & 0.002 \\
\hline June & 3514 & 11.02 & 408ad & 15.5 & $3.78 a$ & 0.037 & 33.9adh & 0.21 & $23.1 \mathrm{bdf}$ & 0.14 & 3.40 & 0.007 & 0.764 & 0.002 \\
\hline July & 3017 & 9.46 & $420 \mathrm{bd}$ & 17.3 & $3.75 a$ & 0.041 & 33.3bfh & 0.23 & $22.1 \mathrm{~g}$ & 0.16 & 3.37 & 0.007 & $0.754 \mathrm{c}$ & 0.002 \\
\hline August & 3016 & 9.46 & $495 \mathrm{cf}$ & 17.0 & $4.00 \mathrm{~b}$ & 0.040 & $29.7 e$ & 0.23 & $22.2 \mathrm{~h}$ & 0.15 & 3.27 & 0.007 & 0.742 & 0.002 \\
\hline September & 3502 & 10.98 & $504 \mathrm{cf}$ & 16.0 & $3.91 b$ & 0.038 & $34.2 \mathrm{ab}$ & 0.21 & $19.9 k$ & 0.15 & 3.37 & 0.007 & $0.751 c$ & 0.002 \\
\hline October & 40 & 0.13 & $420 a b f$ & 124.2 & $3.62 a$ & 0.296 & 32.5abce & 1.72 & $22.7 a$ & 1.12 & $3.45 \mathrm{cdh}$ & 0.051 & $0.800 d$ & 0.017 \\
\hline November & 3131 & 9.82 & $358 a$ & 16.0 & $3.59 a$ & 0.038 & $32.5 \mathrm{c}$ & 0.21 & $23.4 \mathrm{kd}$ & 0.15 & $3.56 f$ & 0.007 & $0.805 d$ & 0.002 \\
\hline December & 1926 & 6.04 & $320 a$ & 21.8 & $3.50 a$ & 0.052 & $33.6 \mathrm{bd}$ & 0.30 & $21.0 \mathrm{a}$ & 0.20 & 3.52fh & 0.009 & $0.781 \mathrm{bd}$ & 0.003 \\
\hline
\end{tabular}

* Values with the same superscript (within a column) show no statistically significant difference at $P>0.05$

Table 5: Least squares means (LSM) and standard errors (SE) of somatic cell count (SCC, $1000 \mathrm{cell} / \mathrm{ml}$ ), somatic cell score (SCS), test-day milk yield (TDM, kg), milk urea content (MU, mg/dl), protein percentage (PP\%) and protein yield (PY, kg) by days in milk (DIM, day) categories (C)

\begin{tabular}{|c|c|c|c|c|c|c|c|c|c|c|c|c|c|c|c|}
\hline \multirow{3}{*}{ C } & \multirow{3}{*}{ DIM, day } & \multicolumn{2}{|c|}{ Observations } & \multicolumn{12}{|c|}{ Trait } \\
\hline & & \multirow{2}{*}{ No. } & \multirow{2}{*}{$\%$} & \multicolumn{2}{|c|}{ SCC } & \multicolumn{2}{|c|}{ SCS } & \multicolumn{2}{|c|}{ MU } & \multicolumn{2}{|c|}{ TDM } & \multicolumn{2}{|c|}{ PP } & \multicolumn{2}{|c|}{ PY } \\
\hline & & & & LSM & SE & LSM & SE & LSM & SE & LSM & SE & LSM & SE & LSM & SE \\
\hline 1 & $\leq 30$ & 2693 & 8.45 & $444 a$ & 21.9 & $3.65 a$ & 0.05 & $29.7 a$ & 0.30 & $24.2 \mathrm{ac}$ & 0.20 & $3.28 a$ & 0.009 & 0.749 & 0.003 \\
\hline 2 & $31-60$ & 3185 & 10.0 & $465 a$ & 20.4 & $3.60 \mathrm{aB}$ & 0.05 & $30.0 a$ & 0.28 & $26.2 b$ & 0.19 & 3.19 & 0.008 & $0.737 a$ & 0.003 \\
\hline 3 & $61-90$ & 3500 & 10.98 & $467 a$ & 19.6 & $3.69 a$ & 0.05 & $31.1 \mathrm{c}$ & 0.27 & $25.7 b$ & 0.18 & $3.25 a$ & 0.008 & $0.746 a$ & 0.003 \\
\hline 4 & $91-120$ & 3466 & 10.88 & $469 a$ & 19.3 & $3.76 a$ & 0.05 & $32.3 b$ & 0.26 & $24.3 a$ & 0.18 & 3.34 & 0.008 & $0.765 b$ & 0.003 \\
\hline 5 & $121-150$ & 3282 & 10.3 & $442 a$ & 19.4 & $3.76 a$ & 0.05 & $32.6 b$ & 0.26 & $23.5 c$ & 0.18 & 3.41 & 0.008 & $0.778 b$ & 0.003 \\
\hline 6 & $151-180$ & 3007 & 9.44 & $421 a$ & 19.8 & $3.77 a$ & 0.05 & $33.1 \mathrm{~b}$ & 0.27 & 22.1 & 0.18 & 3.45 & 0.008 & 0.783bcef & 0.003 \\
\hline 7 & $181-210$ & 2898 & 9.10 & $395 a$ & 20.1 & $3.79 \mathrm{aC}$ & 0.05 & $33.3 b$ & 0.27 & 21.0 & 0.18 & $3.50 b$ & 0.008 & $0.791 \mathrm{~cd}$ & 0.003 \\
\hline 8 & $211-240$ & 2897 & 9.09 & 342 & 20.3 & $3.72 a$ & 0.05 & $33.1 b$ & 0.28 & $20.0 d$ & 0.18 & $3.53 b$ & 0.008 & $0.792 \mathrm{de}$ & 0.003 \\
\hline 9 & $241-270$ & 2726 & 8.56 & 316 & 20.9 & $3.75 a$ & 0.05 & $33.4 b$ & 0.28 & 18.5 & 0.19 & 3.59 & 0.008 & $0.789 d$ & 0.003 \\
\hline 10 & $271-300$ & 2343 & 7.35 & 309 & 22.0 & $3.73 a$ & 0.05 & $33.0 \mathrm{~b}$ & 0.30 & 17.7 & 0.20 & 3.61 & 0.009 & $0.778 f$ & 0.003 \\
\hline 11 & $>300$ & 1866 & 5.86 & 327 & 23.4 & $3.60 \mathrm{a}$ & 0.06 & $31.6 \mathrm{bc}$ & 0.32 & $20.1 d$ & 0.21 & $3.53 b$ & 0.010 & $0.774 b$ & 0.003 \\
\hline
\end{tabular}

( 
Table 8: Least squares means (LSM) and standard errors (SE) of somatic cell count (SCC, $1000 \mathrm{cell} / \mathrm{ml}$ ), somatic cell score (SCS), milk urea content (MU, mg/dl), and test-day milk yield (TDM, $\mathrm{kg}$ ), by protein percent (PP, \%) categories (C)

\begin{tabular}{|c|c|c|c|c|c|c|c|c|c|c|c|}
\hline \multirow{3}{*}{ C } & \multirow{3}{*}{ PP, \% } & \multicolumn{2}{|c|}{ Observations } & \multicolumn{8}{|c|}{ Trait } \\
\hline & & \multirow{2}{*}{ No. } & \multirow{2}{*}{$\%$} & \multicolumn{2}{|c|}{ SCC } & \multicolumn{2}{|c|}{ SCS } & \multicolumn{2}{|c|}{ MU } & \multicolumn{2}{|c|}{ TDM } \\
\hline & & & & LSM & SE & LSM & SE & LSM & SE & LSM & SE \\
\hline 1 & $<3.0$ & 4354 & 13.66 & $267 a$ & 19.1 & 3.28 & 0.05 & $30.8 a$ & 0.27 & $24.7 a$ & 0.18 \\
\hline 2 & $\geq 3.0-3.2$ & 6041 & 18.96 & $310 a$ & 16.7 & 3.45 & 0.04 & $30.8 a$ & 0.23 & $24.6 \mathrm{a}$ & 0.16 \\
\hline 3 & $>3.2-3.4$ & 7167 & 22.49 & $382 b$ & 15.6 & $3.69 a$ & 0.04 & 31.9 & 0.21 & 23.0 & 0.14 \\
\hline 4 & $>3.4-3.6$ & 6500 & 20.40 & $410 b c$ & 16.0 & 3.76ab & 0.04 & $32.8 b$ & 0.22 & 21.5 & 0.15 \\
\hline 5 & $>3.6-3.8$ & 4307 & 13.52 & $454 c$ & 17.9 & $3.90 b$ & 0.04 & $33.4 \mathrm{bc}$ & 0.24 & 20.3 & 0.16 \\
\hline 6 & $>3.8$ & 3494 & 10.97 & 577 & 19.2 & 4.18 & 0.05 & $33.1 \mathrm{c}$ & 0.26 & 18.6 & 0.17 \\
\hline
\end{tabular}

* Least squares Means within the same column with similar superscript are not significantly $(\mathrm{P}>0.05)$ different.

Table 9: Least squares means (LSM) and standard errors (SE) of somatic cell count (SCC, $1000 \mathrm{cell} / \mathrm{ml}$ ), somatic cell score (SCS), test-day milk yield (TDM, kg), protein percentage (PP\%) and protein yield (PY, $\mathrm{kg}$ ) by milk urea content (MU, $\mathrm{mg} / \mathrm{dl}$ ) categories (C)

\begin{tabular}{|c|c|c|c|c|c|c|c|c|c|c|c|c|c|}
\hline \multirow{3}{*}{ C } & \multirow{3}{*}{ MU, Mg/dl } & \multicolumn{2}{|c|}{ Observations } & \multicolumn{10}{|c|}{ Trait } \\
\hline & & \multirow{2}{*}{ No. } & \multirow{2}{*}{$\%$} & \multicolumn{2}{|c|}{ SCC } & \multicolumn{2}{|c|}{ SCS } & \multicolumn{2}{|c|}{ TDM } & \multicolumn{2}{|c|}{ PP } & \multicolumn{2}{|c|}{ PY } \\
\hline & & & & LSM & $\mathrm{SE}$ & LSM & $\mathrm{SE}$ & LSM & $\mathrm{SE}$ & LSM & SE & LSM & SE \\
\hline 1 & $<15$ & 1492 & 4.68 & 546 & 28.1 & 4.10 & 0.07 & 16.7 & 0.25 & $3.38 a$ & 0.011 & 0.733 & 0.004 \\
\hline 2 & $15-25$ & 7842 & 24.61 & $445 a$ & 14.6 & $3.84 a$ & 0.03 & 18.9 & 0.13 & $3.40 a$ & 0.006 & 0.749 & 0.002 \\
\hline 3 & $26-35$ & 11743 & 36.85 & $420 a$ & 13.3 & $3.77 a$ & 0.03 & 21.2 & 0.12 & $3.43 b$ & 0.006 & 0.763 & 0.002 \\
\hline 4 & $36-45$ & 7098 & 22.28 & $348 b$ & 15.1 & $3.58 \mathrm{~b}$ & 0.04 & 22.8 & 0.14 & $3.44 b$ & 0.006 & 0.770 & 0.002 \\
\hline 5 & $46-55$ & 2499 & 7.84 & $333 b$ & 20.3 & $3.60 \mathrm{~b}$ & 0.05 & 24.5 & 0.19 & $3.45 b$ & 0.008 & 0.783 & 0.003 \\
\hline 6 & $>55$ & 1189 & 3.73 & $307 b$ & 26.7 & 3.38 & 0.06 & 28.6 & 0.24 & $3.46 \mathrm{~b}$ & 0.011 & 0.828 & 0.004 \\
\hline
\end{tabular}


Oudah, E. Z. M. 